\title{
Genetic backgrounds and redox conditions influence morphological characteristics and cell differentiation of osteoclasts in mice
}

Shun Narahara*, Haruna Matsushima*, Eiko Sakai ${ }^{\S}$, Yutaka Fukuma, Kazuhisa Nishishita, Kuniaki Okamoto and Takayuki Tsukuba ${ }^{\S}$

Division of Oral Pathopharmacology, Nagasaki University Graduate School of Biomedical Sciences, 1-7-1, Sakamoto, Nagasaki 852-8588, Japan

*These authors contributed equally to this work.

${ }^{\S}$ Corresponding authors

Division of Pathopharmacology, Nagasaki University Graduate School of Biomedical Sciences, Sakamoto 1-7-1, Nagasaki 852-8588, Japan

Phone number: 81-95-819-7654; FAX: 81-95-819-7655

E-mail address: eiko-s@nagasaki-u.ac.jp or tsuta@nagasaki-u.ac.jp

Key words: osteoclasts, C57BL/6, BALB/c, ddY, differentiation,

Abbreviations used in this paper:

OCLs, osteoclasts; RANKL, receptor activator of NF-kB ligand; TRAP, tartrate-resistant acid phosphatase; BMMs, bone-marrow macrophages; NAC, $\mathrm{N}$-acetylcysteine; $\mathrm{H}_{2} \mathrm{O}_{2}$, hydrogen peroxide; M-CSF, macrophage-colony-stimulating factor; NFATc1, nuclear factor of activated T cells cytoplasmic-1; DC-STAM, dendritic cell-specific transmembrane protein; OC-STAMP, Osteoclast stimulatory transmembrane protein; MMP, matrix metalloproteinase; TRAF6, TNF receptor associated factor-6; 


\begin{abstract}
Osteoclasts (OCLs) are multinucleated giant cells, and are formed by the fusion of mononuclear progenitors of monocyte/macrophage lineage. It is known that macrophages derived from different genetic backgrounds exhibit quite distinct characteristics of immune responses. However, it is unknown whether OCLs from different genetic backgrounds show distinct characteristics. In this study, we showed that bone marrow macrophages (BMMs) derived from C57BL/6, BALB/c, and ddY mice exhibited considerably distinct morphological characteristics and cell differentiation into OCLs. The differentiation of BMMs into OCLs was comparatively quicker in the $\mathrm{C} 57 \mathrm{BL} / 6$ and $\mathrm{ddY}$ mice, while that of BALB/c mice was rather slow. Morphologically, ddY OCLs showed a ginat cell with a round shape, C57BL/6 OCLs were of a moderate size with many protrusions and BALB/c OCLs had the smallest size with fewer nuclei. The intracellular signaling of differentiation and expression levels of marker proteins of OCLs were different in the respective strains. Treatment of BMMs from the three different strains with the reducing agent $N$-acetylcysteine (NAC) or with the oxidation agent hydrogen peroxide $\left(\mathrm{H}_{2} \mathrm{O}_{2}\right)$ induced changes in the shape and sizes of the cells and caused distinct patterns of cell differentiation and survival. Thus, genetic backgrounds and redox conditions regulate the morphological characteristics and cell differentiation of OCLs.
\end{abstract}




\section{Introduction}

Osteoclasts (OCLs) are multinucleated giant cells mainly participating in bone resorption (Suda et al., 1999; Teitelbaum and Ross, 2003). OCLs are formed by the fusion of mononuclear progenitors of monocyte/macrophage lineage (Suda et al., 1992). The osteoclast differentiation is regulated by at least two essential cytokines, namely receptor activator of nuclear factor kappa-B ligand (RANKL) and colony-stimulating factor (M-CSF). The TNF-related cytokine RANKL is a key cytokine involved in osteoclast differentiation and activation (Lacey et al., 1998; Yasuda et al., 1998). M-CSF is a type of secreted cytokine that influences hemopoietic stem cells to differentiate into osteoclasts, macrophages or other related cells (Yoshida et al., 1990). In addition to these factors, the osteoclastogenesis is mediated by other factors such as TNF- $\alpha$, IL-1, and IFN- $\beta / \gamma$ (Boyle et al., 2003). Thus, osteoclastogenesis is closely regulated by immune-related cytokines. Recently, a new research field called osteoimmunology, which investigates close regulatory systems between the skeletal and the immune systems has been established (Raggatt and Partridge, 2010; Rho et al., 2004; Takayanagi, 2009).

Immune systems are highly regulated by numerous factors. Among immunological factors, genetic background is a key factor for determining the characteristics of human and mice immune systems (Guler et al., 1996; Rivera and Tessarollo, 2008). In order to investigate genetic backgrounds, C57BL/6 and BALB/c mice have been widely used to analyze the immunopathogenesis of various intracellular infections. In many cases, $\mathrm{C} 57 \mathrm{BL} / 6$ mice are innately resistant to various infections, while BALB/c mice are considerably more susceptible (Autenrieth et al., 1994; Brett and Butler, 1986; Leakey et al., 1998). These different infectious susceptibilities depend on distinct immune responses. Namely, C57BL/6 mice, which are a "Th1-dominant" strain, exclusively induce cell-mediated immune responses after infections, (Hoft et al., 1993) whereas BALB/c mice, which are so-called "Th2-dominant" strain, predominantly evoke antibody responses and are commonly used for the study of allergic responses (Launois et al., 1997). The different genetic backgrounds separately regulate the activation and maturation of macrophages. Macrophages derived from C57BL/6 mice are differentiated to type 1 macrophages (M1) that produced a higher level of NO but a lower level of TGF- $\beta$, whereas macrophages from BALB/c mice are type 2 macrophages (M2) that generate a lower amount of NO but a higher amount of 
TGF- $\beta$ (Mantovani et al., 2007; Mills et al., 2000). Moreover, comparison between the gene expression levels in macrophages of $\mathrm{C} 57 \mathrm{BL} / 6$ and $\mathrm{BALB} / \mathrm{c}$ mice indicate more than 5-fold differences in 63 genes (Kuroda et al., 2007). These findings prompted us to investigate whether macrophages of $\mathrm{C} 57 \mathrm{BL} / 6$ and $\mathrm{BALB} / \mathrm{c}$ mice are distinctively differenciated into OCLs when stimulated by the osteoclast-differentiation factors, including RANKL and M-CSF. However, few studies have investigated the differentiation mechanisms of OCLs from different genetic backgrounds in detail.

In this study, we used $\mathrm{C} 57 \mathrm{BL} / 6$ and $\mathrm{BALB} / \mathrm{c}$ mice to compare osteoclastogenesis in different genetic backgrounds. In addition to these strains, ddY mice were used because they are a popular strain in the mouse-osteoclast culture system whose bonemarrow cells are typically differentiated into giant cells with many nuclei (Udagawa et al., 1990; Udagawa et al., 1999). We show that genetic differences and redox conditions determine the morphological characteristics and cell differentiation of osteoclasts by using in vitro RANKL-induced culture systems. 


\section{Materials and Methods}

Mice

Male BALB/cByJ and C57BL/6 J mice (5-6 weeks old) were purchased from Japan Clea Inc.; male ddY mice (5-6 weeks old) were purchased from Kyudo Co Ltd. These mice were maintained in the Laboratory Animal Research Center at Nagasaki University under specific pathogen-free conditions. All animal experiments were performed according to the guidelines for the care and use of animals approved by the Nagasaki University Animal Care Committee.

\section{Reagents}

M-CSF was purchased from Kyowa Hakko Kogyo. Recombinant RANKL was prepared as previously described ( $\mathrm{Hu}$ et al., 2008). We used the following antibodies (Abs): $\beta$-actin (A5060, Sigma-Aldrich), Src (05-184, Upstate), c-fms (SC692, Santa Cruz), RANK (SC9072, H-300, Santa Cruz), and TRAF6 (SC7221, H-274, Santa Cruz), phospho-ERK1/2 (9101, Thr202/Tyr204, Cell Signaling), phospho-JNK (9251, Thr183/Tyr185, Cell Signaling), phospho-p38 (9211, Thr180/Tyr182, Cell Signaling), phospho-IкB $\alpha$ (2859, Ser32, Cell Signaling), Bim (2819, Cell Signaling), Bax (2772, Cell Signaling), and Bcl-xL (2762, Cell Signaling). Anti-rabbit IgG horseradish peroxidase (HRP)-conjugated antibody (7074) and anti-mouse IgG HRP-conjugated antibody (7076) were purchased from Cell signaling. Cathepsin K Ab was prepared as previously described (Kamiya et al., 1998). All other reagents including PMSF and protease inhibitor cocktail, were purchased from Sigma-Aldrich. Osteo Assay Plate was purchased from Corning.

Cell culture

To isolate bone marrow-derived macrophages (BMMs), marrow cells from the femurs and tibias of mice were cultured in 100-mm polystyrene dish (IWAKI SH90-15E, ASAHI GLASS Co.) overnight in $\alpha$-MEM (Wako Pure Chemicals) containing 10\% FBS with $100 \mathrm{U} / \mathrm{ml}$ of penicillin, and $100 \mu \mathrm{g} / \mathrm{ml}$ of streptomycin in the presence of 
M-CSF $(50 \mathrm{ng} / \mathrm{ml})$ at $37{ }^{\circ} \mathrm{C}$ in $5 \% \mathrm{CO}_{2}$. By harvesting the non-adherent cells, stroma-free bone-marrow cells were plated at $1 \times 10^{7}$ cells $/ 10 \mathrm{ml} / \mathrm{dish}$ in $100-\mathrm{mm}$ tissue culture dish (IWAKI 3020-100, ASAHI GLASS Co.), and were cultured with $50 \mathrm{ng} / \mathrm{ml}$ M-CSF for 3 days to generate BMMs. After non-adherent cells were washed out, BMMs were plated at $2.5 \times 10^{6}$ cells $/ 5 \mathrm{ml} /$ dish in $60-\mathrm{mm}$ dish (IWAKI 3010-060, ASAHI GLASS Co.) for preparation of RNA and cell lysate, or $4 \times 10^{4}$ cells $/ 200$ $\mu \mathrm{L} /$ well in 96 well microplate (IWAKI 3860-096, ASAHI GLASS Co.) for tartrate-resistant acid phosphatase (TRAP) staining, and then further cultured with a new medium containing M-CSF (30 ng/ml) plus RANKL (50 ng/ml) for the indicated times.

\section{Resorption pit assay}

The bone-resorbing activity of OCLs was assayed using Osteo Assay Plate (Corning). BMMs were plated at $2 \times 10^{5}$ cells/ $1 \mathrm{~mL} /$ well in Osteo Assay Plate with M-CSF (30 $\mathrm{ng} / \mathrm{ml})$ plus RANKL (50 $\mathrm{ng} / \mathrm{ml}$ ) for 5 days. Cells were rinsed with Milli-Q water, and $5 \% \mathrm{NaOCl}$ was added to dislodge cells. After five minutes, well was washed with Milli-Q water several times, and dried. Images of resorption pit were taken with a reverse phase microscope (Olympus) and Axio Cam and Axio Vision 3.1 (ZEISS). The ratios of the resorbed area to the total area were measured in 13 optical fields/ individual strain using free hand selection tool of Image J software (http://rsbweb.nih.gov/ij/).

Morphological evaluation of cells

At the end of cultures, the culture medium was removed and cells were fixed with $4 \%$ paraformaldehyde and stained for TRAP as described previously (Hotokezaka et al., 2002). TRAP-positive cells, which had 3 or more nuclei, were regarded as mature OCLs. Images for TRAP staining were taken with a reverse phase microscope (Olympus) and Axio Cam and Axio Vision 3.1 (ZEISS). Nuclei were stained with Hoechst 33258 (1 $\mu \mathrm{g} / \mathrm{ml}$ in PBS) for $5 \mathrm{~min}$. Images for cell area and nuclei counting were taken from 242 cells of ddY, 291 cells of $\mathrm{C} 57 \mathrm{BL} / 6 \mathrm{~J}$, and 321 cells of BALB/cByJ with an all-in-one type fluorescence microscope BZ-9000 (Keyence). Deconvolution for cell area were analyzed by using the BZ analyzer software, dynamic cell count system (Keyence). To 
get clear images suitable for analysis, haze-reduction tool of this software was used. Individual cell boundaries were outlined manually by observer (H. M.). The number of nuclei was counted manually by observer (H. M.). Evaluator (S. N) was blinded to analysis of cell area measurement and nuclei counting. The photograph data were represented as the typical data from three independent experiments.

Reverse transcription and real-time quantitative PCR

Total RNA was extracted using TRIzol Reagent (Invitrogen). Reverse transcription was performed using oligo(dT) ${ }_{15}$ primer (Promega) and Revertra Ace (Toyobo). Quantitative real-time PCR was carried out using a MX3005P QPCR system (Stratagene). cDNA was amplified in Brilliant II FAST SYBR QPCR Master Mix (Stratagene) according to the manufacturer's instructions.

The following primer sets were used:

$\beta$-actin:

5'-ACCCAGATCATGTTTGAGAC-3' forward and

5'-GTCAGGATCTTCATGAGGTAGT-3' reverse,

Cathepsin K:

5'-CAGCTTCCCCAAGATGTGAT-3' forward and

5'-AGCACCAACGAGAGGAGAAA-3' reverse,

DC-STAMP:

5'-CTAGCTGGCTGGACTTCATCC-3' forward and

5'-TCATGCTGTCTAGGAGACCTC-3' reverse,

OC-STAMP:

5'-TGGGCCTCCATATGACCTCGAGTAG-3' forward and

5'-TCAAAGGCTTGTAAATTGGAGGAGT-3' reverse,

NFATC1:

5'-TCATCCTGTCCAACACCAAA-3' forward and

5'-TCACCCTGGTGTTCTTCCTC-3' reverse,

MMP9:

5'-TATTTTTGTGTGGCGTCTGAGAA-3' forward and

5'-GAGGTGGTTTAGCCGGTGAA-3' reverse,

After preheating $\left(95^{\circ} \mathrm{C}\right.$ for $\left.2 \mathrm{~min}\right)$, the samples were amplified by PCR for 40 cycles 
$\left(95^{\circ} \mathrm{C}\right.$ for $5 \mathrm{~s}$ and $60^{\circ} \mathrm{C}$ for $\left.20 \mathrm{~s}\right)$. A standard curve was constructed for each run comprising serial dilutions of pooled cDNA to ensure the integrity of the results. Experiments were performed in triplicate. Each mRNA expression was normalized against $\beta$-actin expression by using the comparative cycle threshold method.

Western blot analysis

BMMs were stimulated with or without RANKL in the presence of M-CSF for the indicated time. Cells were rinsed twice with ice-cold PBS, and lysed in a cell lysis buffer (50 mM Tris-HCl (pH 8.0), 1\% nonidet P-40, 0.5\% sodium deoxycholate, $0.1 \%$ SDS, $150 \mathrm{mM} \mathrm{NaCl}, 1 \mathrm{mM}$ PMSF, and proteinase inhibitor cocktail). The protein concentration of each sample was measured with BCA protein assay reagent (Pierce). Five micrograms of lysate protein was applied to each lane. After SDS-PAGE, proteins were electroblotted onto a polyvinylidene difluoride membrane. The blots were blocked with $5 \% \mathrm{BSA}$ /TBST for $1 \mathrm{~h}$ at room temperature, probed with various antibodies overnight at $4^{\circ} \mathrm{C}$, washed, incubated with HRP-conjugated secondary antibodies, and finally detected with ECL-plus (GE Healthcare Bio-Sciences). The immunoreactive bands were analyzed by LAS1000 (Fuji Photo Film).

Statistical analysis

All values were expressed as means \pm standard deviations. The statistical differences among the three mice strains were evaluated using one-way ANOVA. Tukey-Kramer method was used to identify differences between the strains or concentrations when ANOVA indicated that a significant difference $(* P<0.05$ or $* * P<0.01)$ existed. 


\section{Results}

Differences in morphological and differentiation speed

We first compared morphological characteristics and differentiation of OCLs from ddY, C57BL/6, and BALB/c mice. The BMMs derived from male ddY, C57BL, and BALB mice were cultured with media containing M-CSF plus RANKL for the indicated time such as 48, 60, 72, and $96 \mathrm{~h}$. Comparative studies with the 3 different strains were performed at the same time and under the same conditions. After TRAP staining, ddY/OCLs formed oval-shaped, cytomegalic cells (Fig. 1a, d, g, j). The differentiation of BMMs into OCLs derived from ddY mice reached a maximum at $60 \mathrm{~h}$, and the cell number gradually reduced at 72 or 96 h (Fig. 1m). However, C57BL/OCLs displayed a medium size with many protrusions and were densely stained for TRAP (Fig. 1b, e, h, $\mathrm{k})$. The differentiation of BMMs into OCLs derived from C57BL mice was the quickest. Specifically, C57BL/BMMs matured gradually starting at $48 \mathrm{~h}$, and reached a plateau at $60 \mathrm{~h}$ (Fig. 1m). In contrast, BALB/OCLs exhibited a markedly small size at $60 \mathrm{~h}$ (Fig. 1f). The differentiation from BALB/mice was the slowest (Fig. 1m). The number of BALB/OCLs reached a maximum at $72 \mathrm{~h}$ (Fig. 1i, m). Assay of bone resorbing activity in osteoclasts for 5 days of culture showed that ddY/OCLs have a markedly stronger activity than C57BL/OCLs and BALB/OCLs (Fig. 1n).

Next we calculated the cell areas after TRAP staining at $60 \mathrm{~h}$ (Fig 2a, b, c). The cell area was classified into the following 3 categories: less than $10,000 \mu \mathrm{m}^{2}$, $10,000-100,000 \mu \mathrm{m}^{2}$, more than $100,000 \mu^{2}$. Approximately $80 \%$ of OCLs from BALB/c mice showed a cell area of less than $10,000 \mu \mathrm{m}^{2}$, while about half of OCLs from C57BL/mice showed a cell area of 10,000-100,000 $\mu^{2}$. However, $37 \%$ of OCLs from $\mathrm{ddY} /$ mice displayed a cell area containing more than $100,000 \mu \mathrm{m}^{2}$ (Fig 2d). These results apparently indicate distinct OCL cell areas for different strains.

We counted the nuclear number of the OCLs following nuclear staining with Hoechst 33258. The OCLs from BALB/c mice containing less than 10 nuclei accounted for $86 \%$ of the total number. The cells from C57BL/6 mice containing 11-100 nuclei made up approximately $90 \%$ of the total. About $37 \%$ of OCLs from ddY mice possessed more than 100 nuclei (Fig. 2e). Thus, OCLs from 3 different strains displayed distinct nuclear numbers. 
Intracellular signaling and expression levels of marker proteins of OCLs

Next, we assessed intracellular signaling during differentiation of BMMs into OCLs from the 3 different strains. The 3 different BMMs were cultured with serum-free media for $2 \mathrm{~h}$; subsequently, they were stimulated with RANKL and M-CSF. We evaluated signaling as phosphorylation of $\mathrm{p} 38$, Erk, I $\mathrm{I} \mathrm{B} \alpha$, and JNK by western blotting, since these MAP kinases are required for osteoclastogenesis (Boyle et al., 2003). BMMs from ddY/mice showed enhanced levels of phosphorylation of Erk and I $\mathrm{B} \alpha$ (Fig. 3). C57BL/BMMs displayed weaker levels of phosphorylation of $\mathrm{p} 38$, but comparable levels of phosphorylation of Erk and $\mathrm{I} \kappa \mathrm{B} \alpha$ to those in observed in ddY/osteoclasts (Fig. 3). In contrast, BALB/BMMs exhibited enhanced phosphorylation of $\mathrm{p} 38$, but impaired phosphorylation of Erk, I $\mathrm{BB} \alpha$, and JNK compared with other OCLs (Fig. 3). These results indicated that $\mathrm{BMMs}$ from the 3 different strains showed distinct patterns of the activation levels of $\mathrm{p} 38$, Erk, I $\mathrm{B} \alpha$, and JNK.

To examine differences in the OCLs derived from the 3 distinct strains of mice, we analyzed the expression levels of the mRNAs of various marker proteins of the OCLs. Nuclear factor of activated T cells cytoplasmic-1 (NFATc1) is a master regulator for OCL differentiation through $\mathrm{Ca}^{2+} /$ calmodulin-dependent calcineurin (Takayanagi et al., 2002). Receptor activator of nuclear factor $\kappa \mathrm{B}$ (RANK) is a type I membrane protein that is expressed on the cell surface of OCLs and is implicated in OCL activation (Yasuda et al., 1998). DC-STAM, which was originally discovered as dendritic cell-specific transmembrane protein, is involved in cell-cell fusion in OCLs (Kukita et al., 2004). Osteoclast stimulatory transmembrane protein (OC-STAMP) is an inducible protein in OCL stimulated by RANKL (Yang et al., 2008). Cathepsin K is a lysosomal cysteine ptotease specifically expressed in OCLs, wherease matrix metalloproteinase (MMP)-9, also known as 92-kDa type IV collagenase, is an extracellular proteinase that is released from OCLs and macrophages (Delaisse et al., 2003). We compared the mRNA levels of NFATC1, RANK, DC-STAM, OC-STAMP, cathepsin K, and MMP-9 in BMMs with or without RANKL stimulation.

In ddY/BMMs, markedly higher mRNA levels of OC-STAMP and comparably higher mRNA levels of NFATc1 and RANK were detected (Fig. 4). C57BL/BMMs showed comparably higher mRNA levels of cathepsin $K$ and $M M P-9$, bur lower levels 
of RANK (Fig. 4). However, BALB/BMMs exhibited higher mRNA levels of DC-STAMP, but markedly lower levels of MMP-9 (Fig. 4).

In addition, the signaling molecule c-src is a non-receptor type tyrosine kinase that regulates the formation of actin-rich podosome in the OCLs, while c-fms is a M-CSF receptor (Kim et al., 2010). TNF receptor associated factor-6 (TRAF6) is an adaptor protein linking between several receptors including RANK and Toll/IL-1 family, and some kinases for activation of NF-kB and AP-1 (Lomaga et al., 1999). Bcl-2 related proteins include the pro-apoptotic proteins (Bim and Bax) that induce apoptosis, and the anti-apoptotic protein Bcl-xL that inhibits apoptosis. These Bcl-2 related proteins are known to regulate differentiation, activation and cell survival of osteoclasts (Tanaka et al., 2010). We, therefore, compared the protein levels of signaling molecules such as c-src, c-fms, RANK, TRAF6, Bim, Bax, and Bcl-xL. The protein expression levels of c-fms, RANK, and TRAF6 in ddY/BMMs were higher than those in the other strains (Fig. 5). In addition, the protein expression levels of the apoptosis molecule Bax were higher in ddY/BMMs and C57BL/BMMs than those in BALB/BMMs (Fig. 5). However, slight differences in Src, Bim and Bcl-xL were detected among the 3 different strains (Fig. 5).

Differential morphology and differentiation in OCLs is regulated by redox conditions

Previous studies have demonstrated that glutathione levels in antigen-presenting cells including macrophages modulate the Th1 versus Th2 response pattern (Murata et al., 2002). Considering that C57BL/6 mice are a typical Th1 type strain, whereas $\mathrm{BALB} / \mathrm{c}$ mice are a typical Th2 type strain, the intracellular redox status is probably one of determinants for the strain specificity. Therefore, we assumed that conversion of redox conditions may induce morphological and differentiation changes of OCLs. For this purpose, we investigated whether treatment of cells with the reducing agent $\mathrm{N}$-acetylcysteine (NAC) or with the oxidizing agent hydrogen peroxide $\left(\mathrm{H}_{2} \mathrm{O}_{2}\right)$ induced morphological or differentiation changes of OCLs. RANKL-induced BMMs from ddY, $\mathrm{C} 57 \mathrm{BL} / 6$, and $\mathrm{BALB} / \mathrm{c}$ mice were cultured with or without NAC in the presence of MCSF (30 ng/ml) and RANKL (50 ng/ml) for up to $96 \mathrm{~h}$. In ddY/BMMs, NAC treatment diminished the cell number for $48 \mathrm{~h}$ and $60 \mathrm{~h}$ (Fig. 6). However, the cell number of ddY was conversely increased by treatment at $72 \mathrm{~h}$ or $96 \mathrm{~h}$ in a 
dose-dependent manner (Fig. 6). Importantly, NAC-treated cells at $10 \mathrm{mM}$ for $72 \mathrm{~h}$ morphologically displayed a smaller size with several protrusions (Fig. 6a). In BALB/BMMs, the cell numbers for $60 \mathrm{~h}$ were decreased by more than $10 \mathrm{mM}$ NAC treatment, whereas those for $72 \mathrm{~h}$ were decreased by more than $5 \mathrm{mM}$ NAC treatment (Fig. 7). BALB/cells treated with 5 or $10 \mathrm{mM} \mathrm{NAC} \mathrm{for} 72 \mathrm{~h}$ contained little protrusions but many nuclei (Fig. 7a). In contrast to BALB, NAC treatment at 0.5 or $1.0 \mathrm{mM}$ enhanced osteoclastgenesis of C57BL for $72 \mathrm{~h}$ (Fig. 8). Treatment with $10 \mathrm{mM}$ or 30 $\mathrm{mM}$ almost abolished the cell survival (Fig. 8).

We treated RANKL-induced BMMs with $\mathrm{H}_{2} \mathrm{O}_{2}$ for the indicated time. In ddY/BMMs, $\mathrm{H}_{2} \mathrm{O}_{2}$ treatment inhibited OCL formation in a dose-dependent manner at 60 h (Fig. 9). Conversely, $\mathrm{H}_{2} \mathrm{O}_{2}$ treatment for $96 \mathrm{~h}$ at $0.1 \mathrm{mM}$ augmented the cell proliferation of ddY compared to non-treated cells or cells treated with lower dose (Fig. 9). In addition, treatment with $0.5 \mathrm{mM} \mathrm{H}_{2} \mathrm{O}_{2}$ had powerful cell toxicity for ddY/BMMs (Fig. 9). Similarly, $\mathrm{H}_{2} \mathrm{O}_{2}$ treatment for $60 \mathrm{~h}$ and $72 \mathrm{~h}$ suppressed OCL formation of BALB/BMMs (Fig. 10). However, $0.1 \mathrm{mM} \mathrm{H}_{2} \mathrm{O}_{2}$ treatment for $96 \mathrm{~h}$ increased the proliferation of BALB/BMMs, although more than $0.5 \mathrm{mM} \mathrm{H}_{2} \mathrm{O}_{2}$ treatment completely abolished cell survival (Fig. 10). In case of C57BL/BMMs, $\mathrm{H}_{2} \mathrm{O}_{2}$ treatment for $60 \mathrm{~h}$ and $72 \mathrm{~h}$ suppressed OCL formation in a dose-dependent manner. However, $\mathrm{H}_{2} \mathrm{O}_{2}$ treatment at $0.01 \mathrm{mM}$ for $60 \mathrm{~h}$ slightly increased the cell number, but it was not statistically significant (Fig. 11). C57BL/BMMs morphologically formed giant cells after $60 \mathrm{~h}$ of $0.01 \mathrm{mM} \mathrm{H}_{2} \mathrm{O}_{2}$ treatment (Fig. 11a).

Finally, we evaluated the cell areas after treatment with $\mathrm{NAC}$ or $\mathrm{H}_{2} \mathrm{O}_{2}$, since those of BALB/BMMs treated with $5 \mathrm{mM} \mathrm{NAC}$ at $72 \mathrm{~h}$, or C57BL/ BMMs treated with 0.01 $\mathrm{mM} \mathrm{H} \mathrm{H}_{2} \mathrm{O}_{2}$ at $60 \mathrm{~h}$ were apparently increased in comparison with the non-treated cells (Fig. 12). The NAC treated BALB/BMMs showed an increased cell area compared to the non-treated cells (Fig. 12). However, the $\mathrm{H}_{2} \mathrm{O}_{2}$ treated C57BL/BMMs displayed a slightly increased cell area compared to the non-treated cells (Fig. 12).

These results indicate that NAC treatment morphologically induced ddY and BALB/BMMs to develop little protrusions and many nuclei, which are characteristics of C57BL/OCLs. Conversely, $\mathrm{H}_{2} \mathrm{O}_{2}$-treated C57BL/ BMMs changed to giant cells similar to ddY/OCLs. Concerning cell proliferation, moderate concentrations of NAC treatment enhanced survival of ddY and BALB, but had no inhibitory effect on that of C57BL. However, suitable doses of $\mathrm{H}_{2} \mathrm{O}_{2}$ augmented cell proliferation of C57BL, but delayed 
that of ddY and BALB. Thus, the intracellular redox conditions in the OCLs determine their morphological characteristics and cell proliferation of OCLs from the 3 different strains, namely, ddY, C57BL/6, and BALB/c mice. 


\section{Discussion}

In this study, we demonstrated differences in the morphological characteristics and differentiation of OCLs form ddY, C57BL/6, and BALB/c mice. Observations of morphological characteristics revealed that ddY/OCLs formed cytomegalic cells, and C57BL/OCLs formed a moderately sized cell with many protrusions, whereas BALB/OCLs formed cells of a markedly small size. The differentiation of ddY/BMMs and C57BL/BMMs reached a maximum at $60 \mathrm{~h}$, but BALB/ BMMs had slower differentiation and did not reach a maximum until $72 \mathrm{~h}$. In fact, both treatment with the antioxidant NAC and oxidative stress caused by $\mathrm{H}_{2} \mathrm{O}_{2}$ influenced morphological characteristics and differentiation of BMMs into OCLs in the ddY, C57BL/6, and $\mathrm{BALB} / \mathrm{c}$ mice.

To date, several previous in vivo studies have reported that mouse genetic backgrounds have differential effects on activation of OCLs. Analyses with a particle-induced inflammatory calvarial osteolysis assay revealed that BALB/c mice showed a moderate bone destruction pattern, but C57BL/6 mice showed the most severe bone destruction (Zhang et al., 2008). In contrast, studies with experimental periodontal diseases induced by the bacteria Porphyromonas gingivalis, a major periodontal pathogen, showed that BALB/c mice exhibited high susceptibility to alveolar bone loss, but C57BL/6 mice considerably resistant (Baker et al., 2000). The discrepancies depend on the complex bone-destruction systems, which include OCLs, immune related cells, and other cells. On the other hand, some previous in vitro studies have reported that different genetic backgrounds have differential effects on OCL activation. However, they used co-culture systems containing BMMs and other cells such as osteoblasts, and reported the differentiation of OCLs derived from C57BL/6 and C3H/HeJ (Linkhart et al., 1999) or ddY and ICR (Choi et al., 2007) or A/J, C57BL/6 and C3H/HeJ mice (Gerstenfeld et al., 2010), but not BALB/c mice. However, our in vitro RANKL-induced OCL differentiation system is a simple assay system with BMMs excluding other cells, and is more suitable for evaluation of activation or differentiation of OCLs. Moreover, the previous in vitro studies did not describe detailed morphological characteristics and molecular mechanisms based on changes of redox status. Thus, this study provides evidence of more detailed molecular mechanisms underlining OCL differentiation under redox/oxidative conditions. 
Previously, it was known that antioxidants, including NAC, generally inhibit osteoclastogenesis in a dose-dependent manner (Ha et al., 2004). NAC treatment blocks essential signaling such as activation of Akt, Erk, and NF-kB (Ha et al., 2004), TRF6, JNK, and p38 (Lee et al., 2005). This is attributed to the fact that increased level of reactive oxygen species is essential for the osteoclastogenesis (Lee et al., 2005). Consistent with those studies, NAC inhibited osteoclastogenesis in a dose-dependent manner in C57BL/BBMs in this study. Similarly, at the $48 \mathrm{~h}$ and $60 \mathrm{~h}$, both BALB/BMMs and ddY/BMMs were susceptible to NAC treatment in a dose-dependent manner. In contrast, BALB/BBMs at $96 \mathrm{~h}$ and ddY/BBMs at $72 \mathrm{~h}$ survived at higher doses. Therefore, it is likely that NAC treatment blocks osteoclastogenesis before the differentiation in the 3 different strains, but inhibited cell death after OCL differentiation in BALB/BBMs and ddY/BBMs except C57BL/BBMs.

Addition of $\mathrm{H}_{2} \mathrm{O}_{2}$ also induced strain differences with regard to morphological characteristics and OCL proliferation. A previous study has reported that addition of $\mathrm{H}_{2} \mathrm{O}_{2}$ for $24 \mathrm{~h}$ had no effect on the proliferation and cell survival of OCLs even at a high dose of $0.1 \mathrm{mM}$ (Kim et al., 2010). In this study, however, BALB/BMMs and ddY/ BMMs showed increased cell numbers treated with $0.1 \mathrm{mM} \mathrm{H}_{2} \mathrm{O}_{2}$ at $96 \mathrm{~h}$. In addition, $\mathrm{C} 57 \mathrm{BL} / \mathrm{BMMs}$ treated with $0.01 \mathrm{mM} \mathrm{H}_{2} \mathrm{O}_{2}$ for $60 \mathrm{~h}$ formed giant cells, indicating that $\mathrm{H}_{2} \mathrm{O}_{2}$ addition induced morphological and cell-differentiation changes. The precise mechanisms underlying the distinct effects of $\mathrm{H}_{2} \mathrm{O}_{2}$ on OCL differentiation are unknown at present. However, $\mathrm{H}_{2} \mathrm{O}_{2}$ addition to $\mathrm{BMMs}$ caused activation of MAP kinase-cascades such as Erk, JNK and p38, which are essential for osteoclastogenesis. ROS is a physiological second messenger in RANKL signaling, essential for osteoclastogenesis (Kim et al., 2010). Therefore, $\mathrm{H}_{2} \mathrm{O}_{2}$ exposure for a long time probably affects certain signaling for osteoclastogenesis.

These redox-modulating agents, namely, $\mathrm{NAC}$ and $\mathrm{H}_{2} \mathrm{O}_{2}$ may have different effects on cells before and after reaching the differentiation peak. It is likely that the oxidant $\mathrm{H}_{2} \mathrm{O}_{2}$ causes late differentiation of OCLs. The differentiation peak of BMMs without $\mathrm{H}_{2} \mathrm{O}_{2}$ in ddY or BALB was $60 \mathrm{~h}$ or $72 \mathrm{~h}$, whereas it in the presence of $0.1 \mathrm{mM} \mathrm{H}_{2} \mathrm{O}_{2}$ it was delayed to $72 \mathrm{~h}$ or $96 \mathrm{~h}$ respectively. On the other hand, it is likely that the antioxidant NAC causes morphological changes. Incubation of ddY/BMMs or BALB/BMMs with $10 \mathrm{mM}$ NAC for $72 \mathrm{~h}$ induced protrusions, which is a characteristic of C57BL/BMMs. Thus, a change in the redox status may have effects before and after 
OCL differentiation.

Numerous immunological studies have demonstrated that characteristics of macrophages derived from $\mathrm{C} 57 \mathrm{BL} / 6$ and $\mathrm{BALB} / \mathrm{c}$ mice are quite different. C57BL macrophages are classified as M1 macrophages that produced a higher level of NO but a lower level of TGF- $\beta$, whereas BALB/macrophages are M2 macrophages that generate a lower amount of NO but a higher amount of TGF- $\beta$ (Kuroda et al., 2007; Mantovani et al., 2007; Mills et al., 2000). Moreover, M2 macrophages are distinguished from other types by several markers, including the IL-4 receptor, mannose receptor, Arg1, Fizz1, PPAR $\gamma$, and Ym1/2 (Fairweather and Cihakova, 2009). Both M1 and M2 macrophages are considered to play important roles for development of diseases. The present study showed that BMMs derived from C57BL/6 and BALB/c mice displayed considerably distinct morphological characteristics and cell differentiation of OCLs.

In conclusion, OCLs from ddY, C57BL/6, and BALB/c mice showed differences in their morphological characteristics and cell differentiation. Stimulation of BMMs with the redox-modulating agents, namely, $\mathrm{NAC}$ and $\mathrm{H}_{2} \mathrm{O}_{2}$ induced differential effects on the morphological characteristics and cell differentiation of each strain. Our data provide to further the understanding of the influence of the differences in genetic backgrounds on osteoclastogenesis. 


\section{Acknowledgments}

This work was supported in part by grants-in-aid for Scientific Research from the Ministry of Education, Science and Culture of Japan (E.S, T.T). 


\section{References}

Autenrieth I.B., Beer M., Bohn E., Kaufmann S.H., Heesemann J. (1994) Immune responses to Yersinia enterocolitica in susceptible BALB/c and resistant C57BL/6 mice: an essential role for gamma interferon. Infect Immun 62:2590-2599.

Baker P.J., Dixon M., Roopenian D.C. (2000) Genetic control of susceptibility to Porphyromonas gingivalis-induced alveolar bone loss in mice. Infect Immun 68:5864-5868.

Boyle W.J., Simonet W.S., Lacey D.L. (2003) Osteoclast differentiation and activation. Nature 423:337-342.

Brett S.J., Butler R. (1986) Resistance to Mycobacterium lepraemurium is correlated with the capacity to generate macrophage activating factor(s) in response to mycobacterial antigens in vitro. Immunology 59:339-345.

Choi H.G., Kim J.M., Kim B.J., Yoo Y.J., Cha J.H. (2007) Mouse strain-dependent osteoclastogenesis in response to lipopolysaccharide. J Microbiol 45:566-571.

Delaisse J.M., Andersen T.L., Engsig M.T., Henriksen K., Troen T., Blavier L. (2003) Matrix metalloproteinases (MMP) and cathepsin $\mathrm{K}$ contribute differently to osteoclastic activities. Microsc Res Tech 61:504-513.

Fairweather D., Cihakova D. (2009) Alternatively activated macrophages in infection and autoimmunity. J Autoimmun 33:222-230.

Gerstenfeld L.C., McLean J., Healey D.S., Stapleton S.N., Silkman L.J., Price C., Jepsen K.J. (2010) Genetic variation in the structural pattern of osteoclast activity during post-natal growth of mouse femora. Bone 46:1546-1554.

Guler M.L., Gorham J.D., Hsieh C.S., Mackey A.J., Steen R.G., Dietrich W.F., Murphy K.M. (1996) Genetic susceptibility to Leishmania: IL-12 responsiveness in TH1 cell development. Science 271:984-987.

Ha H., Kwak H.B., Lee S.W., Jin H.M., Kim H.M., Kim H.H., Lee Z.H. (2004) Reactive oxygen species mediate RANK signaling in osteoclasts. Exp Cell Res 301:119-127.

Hoft D.F., Lynch R.G., Kirchhoff L.V. (1993) Kinetic analysis of antigen-specific immune responses in resistant and susceptible mice during infection with Trypanosoma cruzi. J Immunol 151:7038-7047. 
Hotokezaka H., Sakai E., Kanaoka K., Saito K., Matsuo K., Kitaura H., Yoshida N., Nakayama K. (2002) U0126 and PD98059, specific inhibitors of MEK, accelerate differentiation of RAW264.7 cells into osteoclast-like cells. J Biol Chem 277:47366-47372.

Hu J.P., Nishishita K., Sakai E., Yoshida H., Kato Y., Tsukuba T., Okamoto K. (2008) Berberine inhibits RANKL-induced osteoclast formation and survival through suppressing the NF-kappaB and Akt pathways. Eur J Pharmacol 580:70-79.

Kamiya T., Kobayashi Y., Kanaoka K., Nakashima T., Kato Y., Mizuno A., Sakai H. (1998) Fluorescence microscopic demonstration of cathepsin K activity as the major lysosomal cysteine proteinase in osteoclasts. J Biochem 123:752-759.

Kim M.S., Yang Y.M., Son A., Tian Y.S., Lee S.I., Kang S.W., Muallem S., Shin D.M. (2010) RANKL-mediated reactive oxygen species pathway that induces long lasting $\mathrm{Ca} 2+$ oscillations essential for osteoclastogenesis. J Biol Chem 285:6913-6921.

Kukita T., Wada N., Kukita A., Kakimoto T., Sandra F., Toh K., Nagata K., Iijima T., Horiuchi M., Matsusaki H., Hieshima K., Yoshie O., Nomiyama H. (2004) RANKL-induced DC-STAMP is essential for osteoclastogenesis. J Exp Med 200:941-946.

Kuroda E., Noguchi J., Doi T., Uematsu S., Akira S., Yamashita U. (2007) IL-3 is an important differentiation factor for the development of prostaglandin E2-producing macrophages between $\mathrm{C} 57 \mathrm{BL} / 6$ and $\mathrm{BALB} / \mathrm{c}$ mice. Eur $\mathrm{J}$ Immunol 37:2185-2195.

Lacey D.L., Timms E., Tan H.L., Kelley M.J., Dunstan C.R., Burgess T., Elliott R., Colombero A., Elliott G., Scully S., Hsu H., Sullivan J., Hawkins N., Davy E., Capparelli C., Eli A., Qian Y.X., Kaufman S., Sarosi I., Shalhoub V., Senaldi G., Guo J., Delaney J., Boyle W.J. (1998) Osteoprotegerin ligand is a cytokine that regulates osteoclast differentiation and activation. Cell 93:165-176.

Launois P., Maillard I., Pingel S., Swihart K.G., Xenarios I., Acha-Orbea H., Diggelmann H., Locksley R.M., MacDonald H.R., Louis J.A. (1997) IL-4 rapidly produced by $\mathrm{V}$ beta $4 \mathrm{~V}$ alpha $8 \mathrm{CD} 4+\mathrm{T}$ cells instructs $\mathrm{Th} 2$ development and susceptibility to Leishmania major in BALB/c mice. Immunity 6:541-549.

Leakey A.K., Ulett G.C., Hirst R.G. (1998) BALB/c and C57Bl/6 mice infected with virulent Burkholderia pseudomallei provide contrasting animal models for the 
acute and chronic forms of human melioidosis. Microb Pathog 24:269-275.

Lee N.K., Choi Y.G., Baik J.Y., Han S.Y., Jeong D.W., Bae Y.S., Kim N., Lee S.Y. (2005) A crucial role for reactive oxygen species in RANKL-induced osteoclast differentiation. Blood 106:852-859.

Linkhart T.A., Linkhart S.G., Kodama Y., Farley J.R., Dimai H.P., Wright K.R., Wergedal J.E., Sheng M., Beamer W.G., Donahue L.R., Rosen C.J., Baylink D.J. (1999) Osteoclast formation in bone marrow cultures from two inbred strains of mice with different bone densities. J Bone Miner Res 14:39-46.

Lomaga M.A., Yeh W.C., Sarosi I., Duncan G.S., Furlonger C., Ho A., Morony S., Capparelli C., Van G., Kaufman S., van der Heiden A., Itie A., Wakeham A., Khoo W., Sasaki T., Cao Z., Penninger J.M., Paige C.J., Lacey D.L., Dunstan C.R., Boyle W.J., Goeddel D.V., Mak T.W. (1999) TRAF6 deficiency results in osteopetrosis and defective interleukin-1, CD40, and LPS signaling. Genes Dev 13:1015-1024.

Mantovani A., Sica A., Locati M. (2007) New vistas on macrophage differentiation and activation. Eur J Immunol 37:14-16.

Mills C.D., Kincaid K., Alt J.M., Heilman M.J., Hill A.M. (2000) M-1/M-2 macrophages and the Th1/Th2 paradigm. J Immunol 164:6166-73.

Murata Y., Shimamura T., Hamuro J. (2002) The polarization of T(h)1/T(h)2 balance is dependent on the intracellular thiol redox status of macrophages due to the distinctive cytokine production. Int Immunol 14:201-12.

Raggatt L.J., Partridge N.C. (2010) Cellular and molecular mechanisms of bone remodeling. J Biol Chem 285:25103-25108.

Rho J., Takami M., Choi Y. (2004) Osteoimmunology: interactions of the immune and skeletal systems. Mol Cells 17:1-9.

Rivera J., Tessarollo L. (2008) Genetic background and the dilemma of translating mouse studies to humans. Immunity 28:1-4.

Suda T., Takahashi N., Martin T.J. (1992) Modulation of osteoclast differentiation. Endocr Rev 13:66-80.

Suda T., Takahashi N., Udagawa N., Jimi E., Gillespie M.T., Martin T.J. (1999) Modulation of osteoclast differentiation and function by the new members of the tumor necrosis factor receptor and ligand families. Endocr Rev 20:345-57.

Takayanagi H. (2009) Osteoimmunology and the effects of the immune system on bone. 
Nat Rev Rheumatol 5:667-676.

Takayanagi H., Kim S., Koga T., Nishina H., Isshiki M., Yoshida H., Saiura A., Isobe M., Yokochi T., Inoue J., Wagner E.F., Mak T.W., Kodama T., Taniguchi T. (2002) Induction and activation of the transcription factor NFATc1 (NFAT2) integrate RANKL signaling in terminal differentiation of osteoclasts. Dev Cell 3:889-901.

Tanaka S., Wakeyama H., Akiyama T., Takahashi K., Amano H., Nakayama K.I., Nakamura K. (2010) Regulation of osteoclast apoptosis by bcl-2 family protein bim and caspase-3. Adv Exp Med Biol 658:111-116.

Teitelbaum S.L., Ross F.P. (2003) Genetic regulation of osteoclast development and function. Nat Rev Genet 4:638-649.

Udagawa N., Takahashi N., Akatsu T., Tanaka H., Sasaki T., Nishihara T., Koga T., Martin T.J., Suda T. (1990) Origin of osteoclasts: mature monocytes and macrophages are capable of differentiating into osteoclasts under a suitable microenvironment prepared by bone marrow-derived stromal cells. Proc Natl Acad Sci U S A 87:7260-7264.

Udagawa N., Takahashi N., Jimi E., Matsuzaki K., Tsurukai T., Itoh K., Nakagawa N., Yasuda H., Goto M., Tsuda E., Higashio K., Gillespie M.T., Martin T.J., Suda T. (1999) Osteoblasts/stromal cells stimulate osteoclast activation through expression of osteoclast differentiation factor/RANKL but not macrophage colony-stimulating factor: receptor activator of NF-kappa B ligand. Bone 25:517-523.

Yang M., Birnbaum M.J., MacKay C.A., Mason-Savas A., Thompson B., Odgren P.R. (2008) Osteoclast stimulatory transmembrane protein (OC-STAMP), a novel protein induced by RANKL that promotes osteoclast differentiation. J Cell Physiol 215:497-505.

Yasuda H., Shima N., Nakagawa N., Yamaguchi K., Kinosaki M., Mochizuki S., Tomoyasu A., Yano K., Goto M., Murakami A., Tsuda E., Morinaga T., Higashio K., Udagawa N., Takahashi N., Suda T. (1998) Osteoclast differentiation factor is a ligand for osteoprotegerin/osteoclastogenesis-inhibitory factor and is identical to TRANCE/RANKL. Proc Natl Acad Sci U S A 95:3597-3602.

Yoshida H., Hayashi S., Kunisada T., Ogawa M., Nishikawa S., Okamura H., Sudo T., Shultz L.D. (1990) The murine mutation osteopetrosis is in the coding region of 
the macrophage colony stimulating factor gene. Nature 345:442-444.

Zhang C., Tang T., Ren W., Zhang X., Dai K. (2008) Influence of mouse genetic background on wear particle-induced in vivo inflammatory osteolysis. Inflamm Res 57:211-215. 


\section{Figure Legends}

Fig. 1 Differences in the morphological characteristics and the differentiation rate of OCLs

BMMs derived from ddY, C57BL/6, and BALB/c mice were respectively cultured with M-CSF (30 ng/ml), and RANKL (50 ng/ml) for the indicated times (48, 60, 72, and 96 h). a-l The cells were fixed and stained for TRAP. Bars $200 \mu \mathrm{m}$. m The number of TRAP-positive multinucleated cells was counted at each indicated times. n Bone resorbing activity of osteoclasts for 5 days of culture was assayed by Osteo Assay Plate. The resorption area was determined by Image $\mathrm{J}$ software. $P$ values $(* P<0.05$ or $* * P<$ $0.01)$ were determined by ANOVA.

Fig. 2 Comparison of the cell area and the nuclear number a-c The matured osteoclasts were stained for TRAP. Bars $100 \mu \mathrm{m}$. d The cell areas were measured by an all-in-one type fluorescence microscope BZ-9000 supplemented with the software BZ-Him (Keyence, Osaka, Japan), and classified as less than 10,000 $\mu^{2}$ (black bar), 10,000-100,000 $\mu \mathrm{m}^{2}$ (gray bar), or more than $100,000 \mu \mathrm{m}^{2}$ (white bar). e The nuclear numbers were counted and classified as less than 10 (black bar), 11-100 (gray bar), or more than 100 (white bar)

Fig. 3 Differences in essential signaling patterns during osteoclastogenesis BMMs were stimulated with RANKL $(100 \mathrm{ng} / \mathrm{ml})$ for the indicated time $(0,5,10,15$, 30 , and $60 \mathrm{~min})$. Cell lysates with equal amounts of protein were subjected to SDS-PAGE, followed by western blotting with antibodies to p-p38, p-Erk, p- I $\mathrm{B} \alpha$, p-JNK and B-actin. (C), C57BL/BMMs; (B), BALB/BMMs; (D), ddY/BMMs.

Fig. 4 Comparison of mRNA expression levels of various osteoclast marker proteins BMMs were cultured for $24 \mathrm{~h}$ with $50 \mathrm{ng} / \mathrm{ml}$ RANKL and $30 \mathrm{ng} / \mathrm{ml}$ M-CSF. Total RNA was subjected to quantitative RT-PCR analysis with specific primers for NFATC1, RANK, DC-STAMP, OC-STAMP, cathepsin K, and MMP-9. The mRNA levels were normalized to $\beta$-actin transcript and expressed relative to controls. Data shown represent 3 independent experiments (mean \pm SD). (D), ddY/BMMs; (C), C57BL/BMMs; (B), 


\section{BALB/BMMs.}

Fig. 5 Comparison of protein expression levels of various signaling proteins in OCLs BMMs were cultured with RANKL $(50 \mathrm{ng} / \mathrm{ml})$ in the presence of M-CSF (30 ng/ml) for the indicated time $(0,24,48$, and $72 \mathrm{~h})$. The same protein amounts of cell lysates were subjected to SDS-PAGE followed by western blotting with antibodies to Src, c-fms, RANK, TRAF6, Bim Bax, Bcl-xl and B-actin. (D), ddY/BMMs; (C), C57BL/BMMs; (B), BALB/BMMs.

Fig. 6 Effects of NAC on the morphological characteristics and cell differentiation of ddY/BMMs

The cells were treated with various concentrations of NAC $(0,0.1,0.5,1,5,10$, and 30 $\mathrm{mM})$ in the presence of RANKL $(50 \mathrm{ng} / \mathrm{ml})$ and M-CSF $(30 \mathrm{ng} / \mathrm{ml})$ for the indicated times $(48,60,72$ and $96 \mathrm{~h})$. Cells were fixed and stained for TRAP. a A representative example is shown. Bars $200 \mu \mathrm{m}$. b The number of TRAP-positive multinucleated osteoclasts was counted. $P$ values $\left({ }^{*} P<0.05\right.$ or $\left.* * P<0.01\right)$ were determined by ANOVA.

Fig. 7 Effects of NAC on the morphological characteristics and cell differentiation of BALB/BMMs

The cells were treated with various concentration of NAC $(0,0.1,0.5,1,5,10$, and 30 $\mathrm{mM})$ in the presence of RANKL $(50 \mathrm{ng} / \mathrm{ml})$ and M-CSF $(30 \mathrm{ng} / \mathrm{ml})$ for the indicated times (48, 60, 72 and 96 h). Cells were fixed and stained for TRAP. a. A representative example is shown. Bars $200 \mu \mathrm{m}$. b The number of TRAP-positive multinucleated osteoclasts was counted. $P$ values $\left({ }^{*} P<0.05\right.$ or $\left.* * P<0.01\right)$ were determined by ANOVA.

Fig. 8 Effects of NAC on the morphological characteristics and cell differentiation of C57BL/BMMs

The cells were treated with various concentration of NAC $(0,0.1,0.5,1,5,10$, and 30 $\mathrm{mM})$ in the presence of RANKL (50 ng/ml) and M-CSF $(30 \mathrm{ng} / \mathrm{ml})$ for the indicated times $(48,60,72$ and $96 \mathrm{~h})$. Cells were fixed and stained for TRAP. a A representative example is shown. Bars $200 \mu \mathrm{m}$. b The number of TRAP-positive multinucleated 
osteoclasts was counted. $P$ value $(* P<0.05$ or $* * P<0.01)$ were determined by ANOVA.

Fig. 9 Effects of $\mathrm{H}_{2} \mathrm{O}_{2}$ on the morphological characteristics and cell differentiation of ddY/BMMs

The cells were treated with various concentration of $\mathrm{H}_{2} \mathrm{O}_{2}(0,0.01,0.05,0.1$, and 0.5 $\mathrm{mM})$ in the presence of RANKL $(50 \mathrm{ng} / \mathrm{ml})$ and M-CSF $(30 \mathrm{ng} / \mathrm{ml})$ for the indicated times (48, 60, 72 and 96 h). Cells were fixed and stained for TRAP. a A representative example is shown Bars $200 \mu \mathrm{m}$. b The number of TRAP-positive multinucleated osteoclasts was counted. $P$ values $(* P<0.05$ or $* * P<0.01)$ were determined by ANOVA.

Fig. 10 Effects of $\mathrm{H}_{2} \mathrm{O}_{2}$ on morphological characteristics and cell differentiation of BALB/BMMs

The cells were treated with various concentration of $\mathrm{H}_{2} \mathrm{O}_{2}(0,0.01,0.05,0.1$, and 0.5 $\mathrm{mM})$ in the presence of RANKL $(50 \mathrm{ng} / \mathrm{ml})$ and M-CSF $(30 \mathrm{ng} / \mathrm{ml})$ for the indicated times (48, 60, 72 and $96 \mathrm{~h})$. Cells were fixed and stained for TRAP. a A representative example is shown. Bars $200 \mu \mathrm{m}$. b The number of TRAP-positive multinucleated osteoclasts was counted. $P$ values $\left({ }^{*} P<0.05\right.$ or $\left.{ }^{* *} P<0.01\right)$ were determined by ANOVA.

Fig. 11 Effects of $\mathrm{H}_{2} \mathrm{O}_{2}$ on the morphological characteristics and cell differentiation of C57BL/BMMs

The cells were treated with various concentration of $\mathrm{H}_{2} \mathrm{O}_{2}(0,0.01,0.05,0.1$, and 0.5 $\mathrm{mM})$ in the presence of RANKL $(50 \mathrm{ng} / \mathrm{ml})$ and M-CSF $(30 \mathrm{ng} / \mathrm{ml})$ for the indicated times (48, 60, 72 and 96 h). Cells were fixed and stained for TRAP. a A representative example is shown. Bars $200 \mu \mathrm{m}$. b The number of TRAP-positive multinucleated osteoclasts was counted. $P$ values $(* P<0.05$ or $* * P<0.01)$ were determined by ANOVA.

Fig. 12 The cell area of NAC treated BALB/BMMs or $\mathrm{H}_{2} \mathrm{O}_{2}$ treated C57BL/BMMs.

a BALB/BMMs were treated with or without $5 \mathrm{mM} \mathrm{NAC}$ at $72 \mathrm{~h}$. The cell areas were measured and classified as less than $10,000 \mu \mathrm{m}^{2}$ (black bar), 10,000-100,000 $\mu^{2}$ (gray 
bar), or more than $100,000 \mu \mathrm{m}^{2}$ (white bar)

b C57BL/ BMMs were treated with or without $0.01 \mathrm{mM} \mathrm{H}_{2} \mathrm{O}_{2}$ at $60 \mathrm{~h}$. The cell areas were measured and classified as less than $10,000 \mu \mathrm{m}^{2}$ (black bar), 10,000-50,000 $\mu \mathrm{m}^{2}$ (gray bar), or more than $50,000 \mu \mathrm{m}^{2}$ (white bar) 


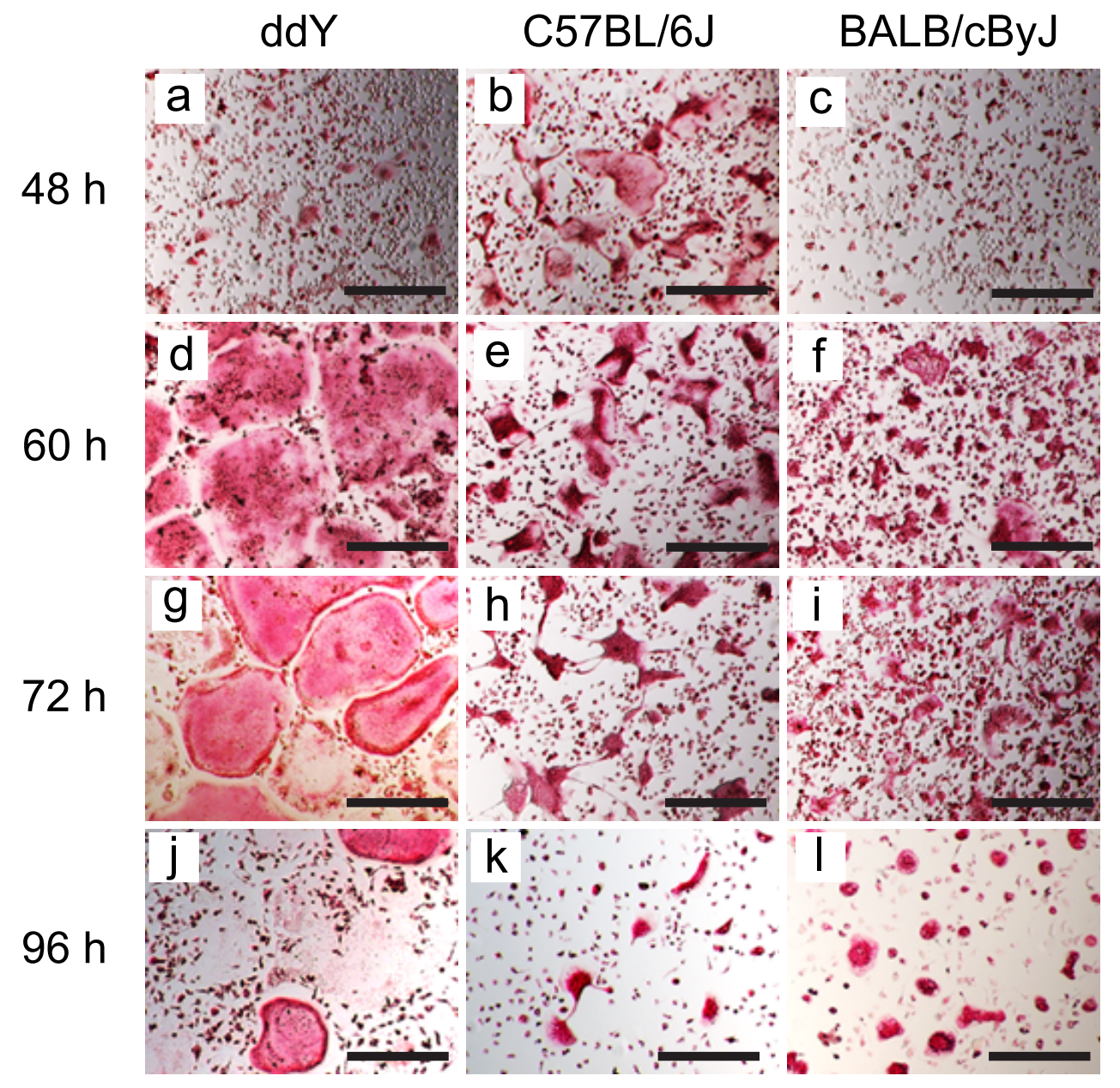

$\mathrm{m}$

$\mathrm{n}$

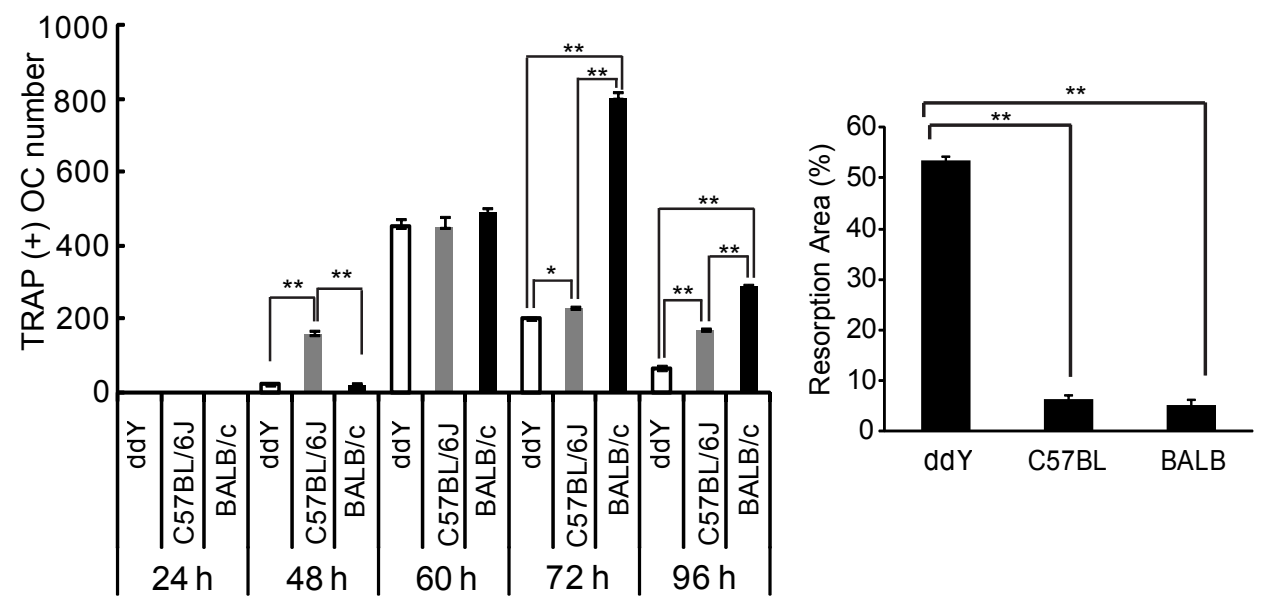

Fig. 1 

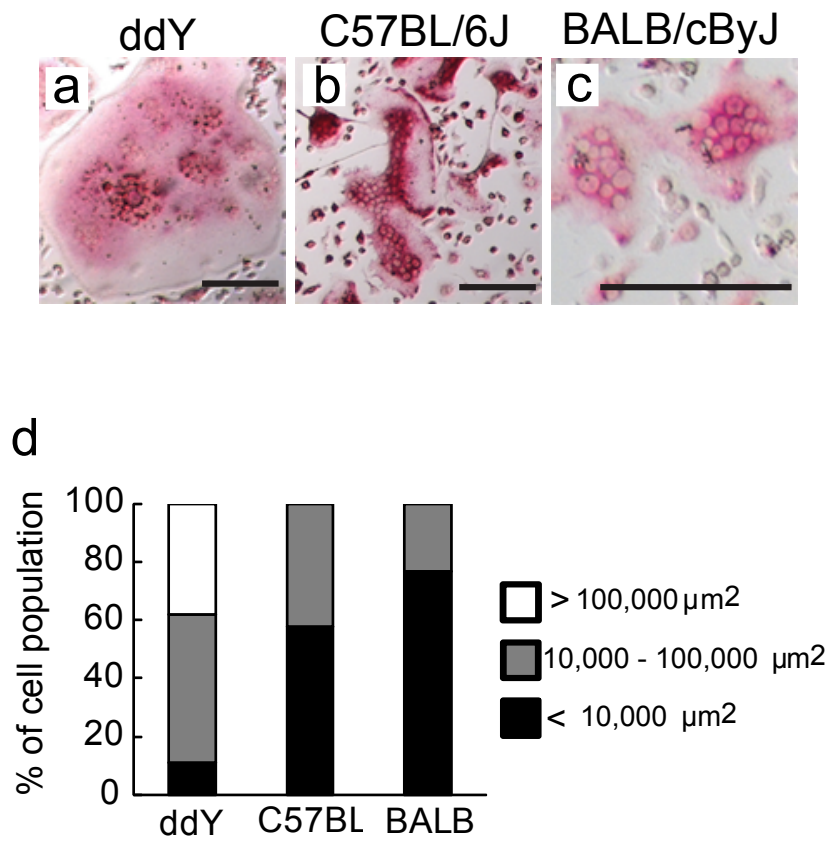

e

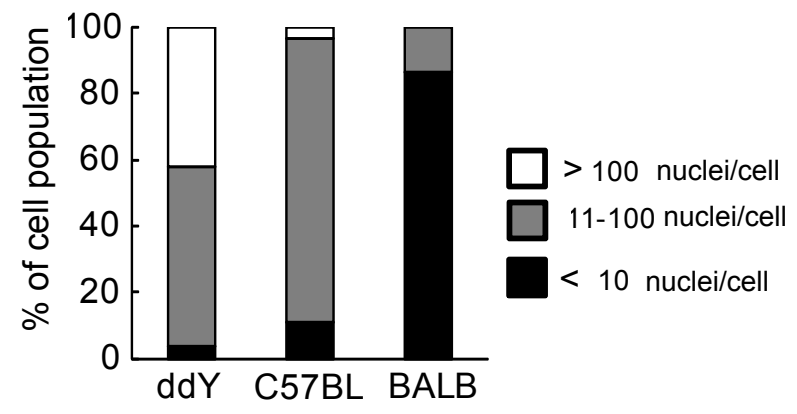

Fig. 2 


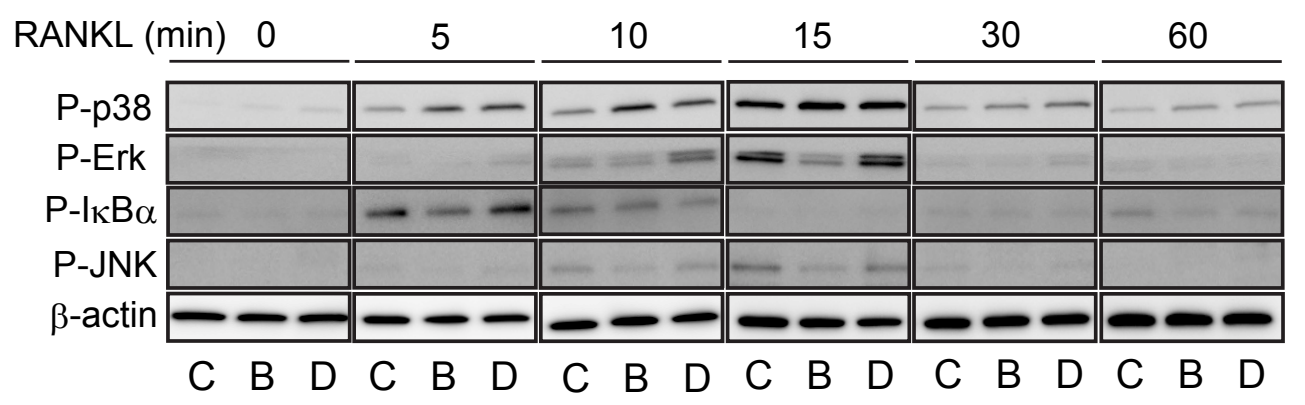

Fig. 3 


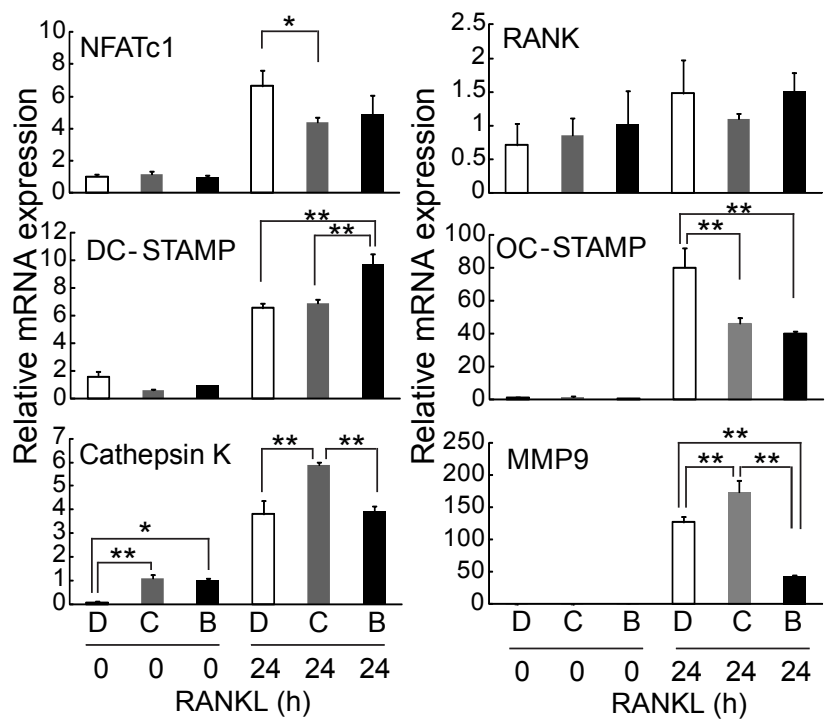

Fig. 4 


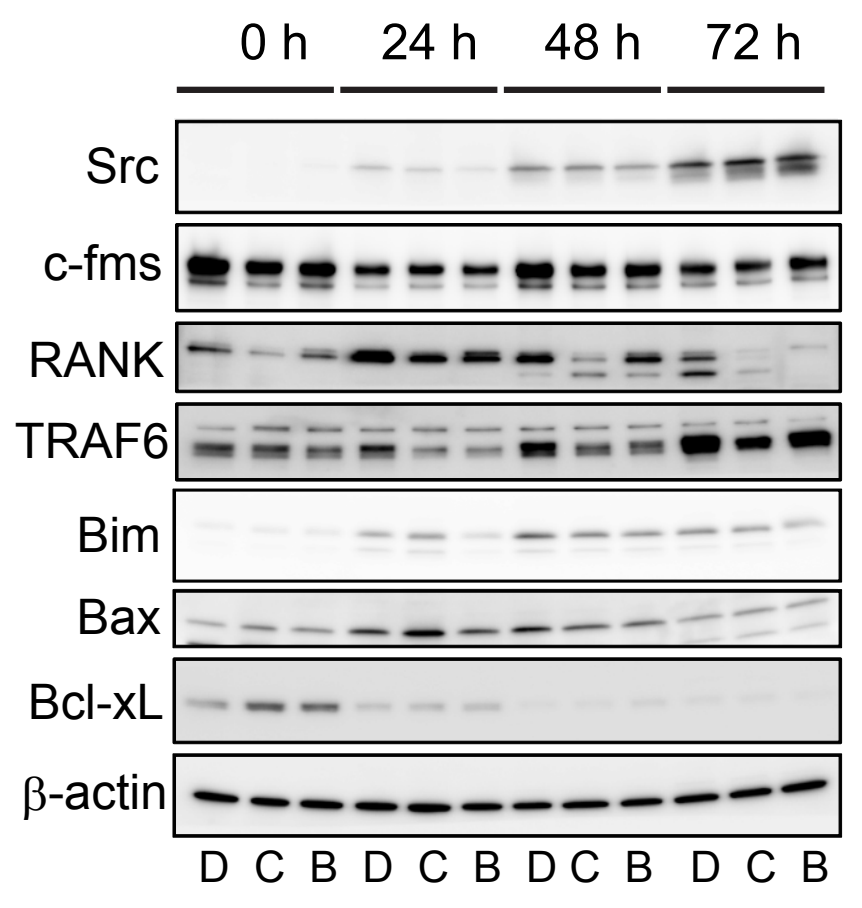

Fig. 5 


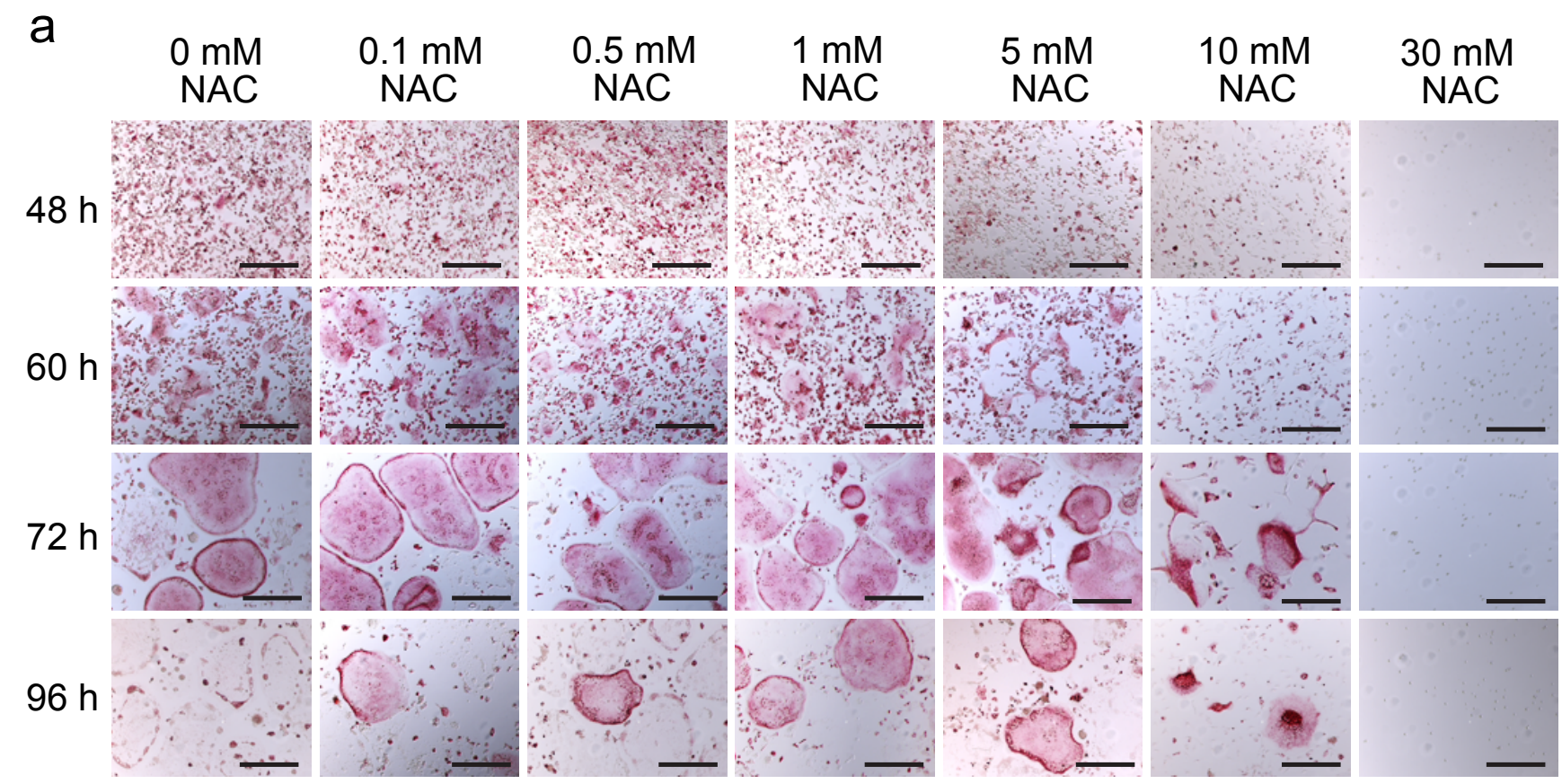

b

ddY / NAC

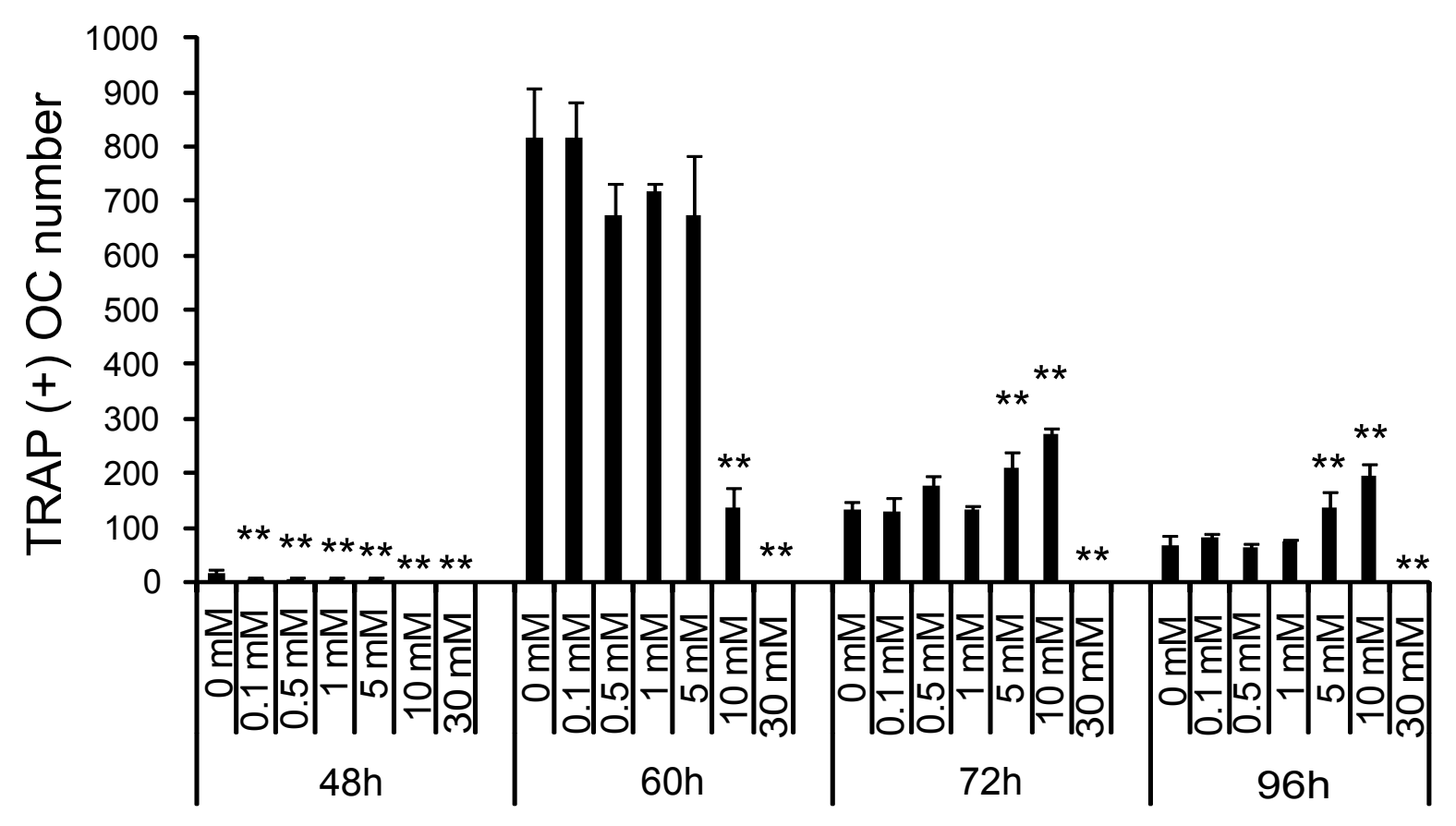

Fig. 6 
a

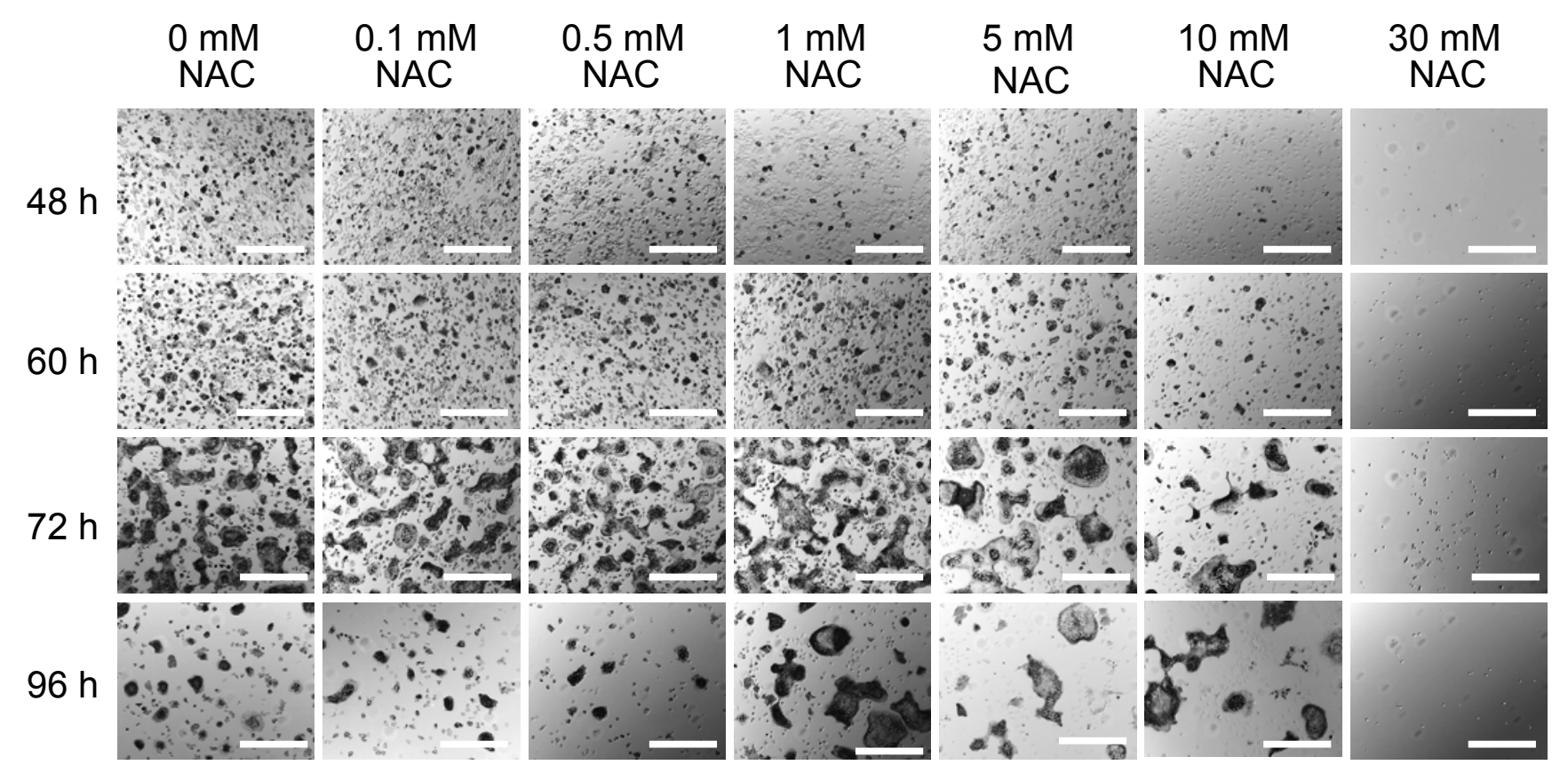

b

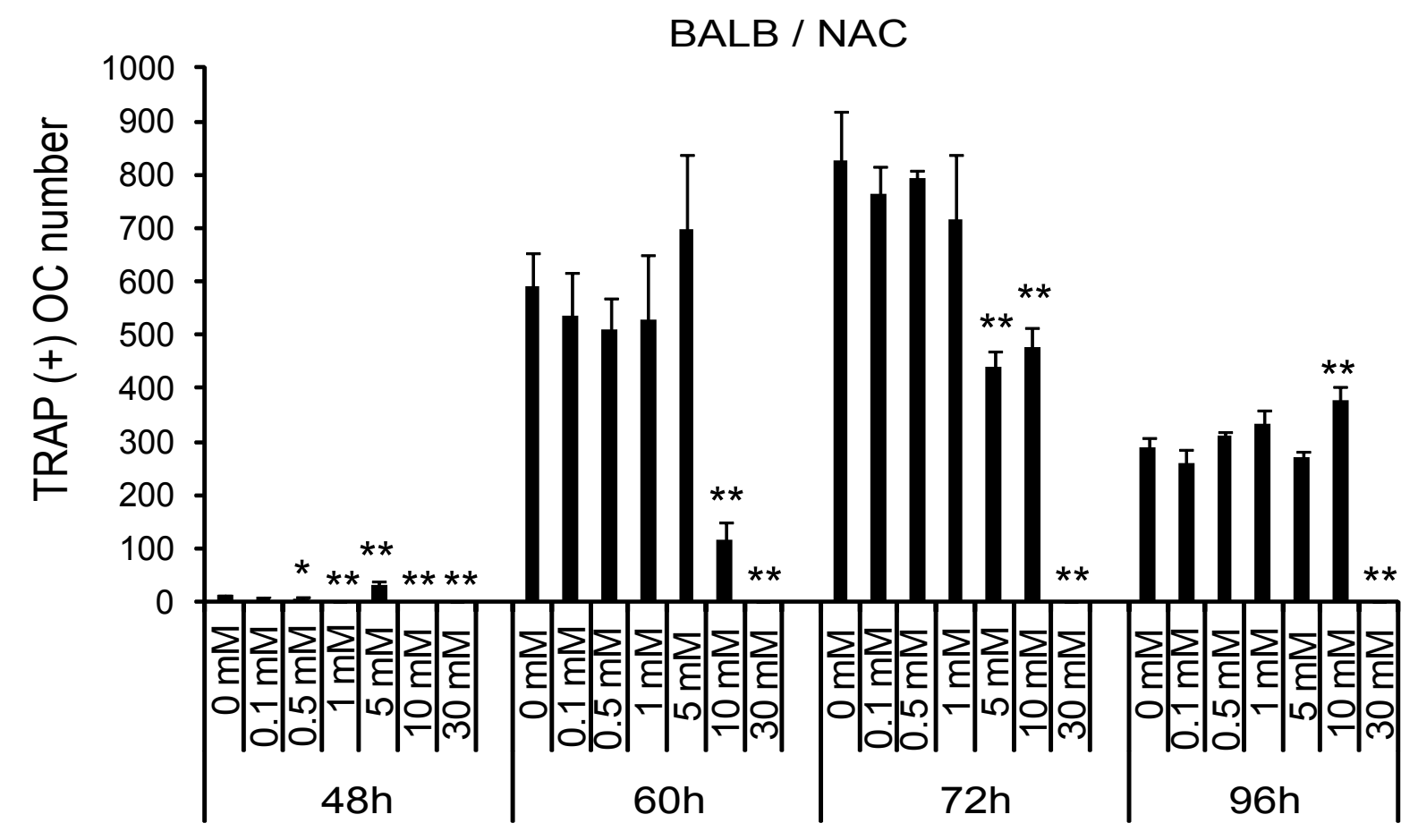

Fig. 7 


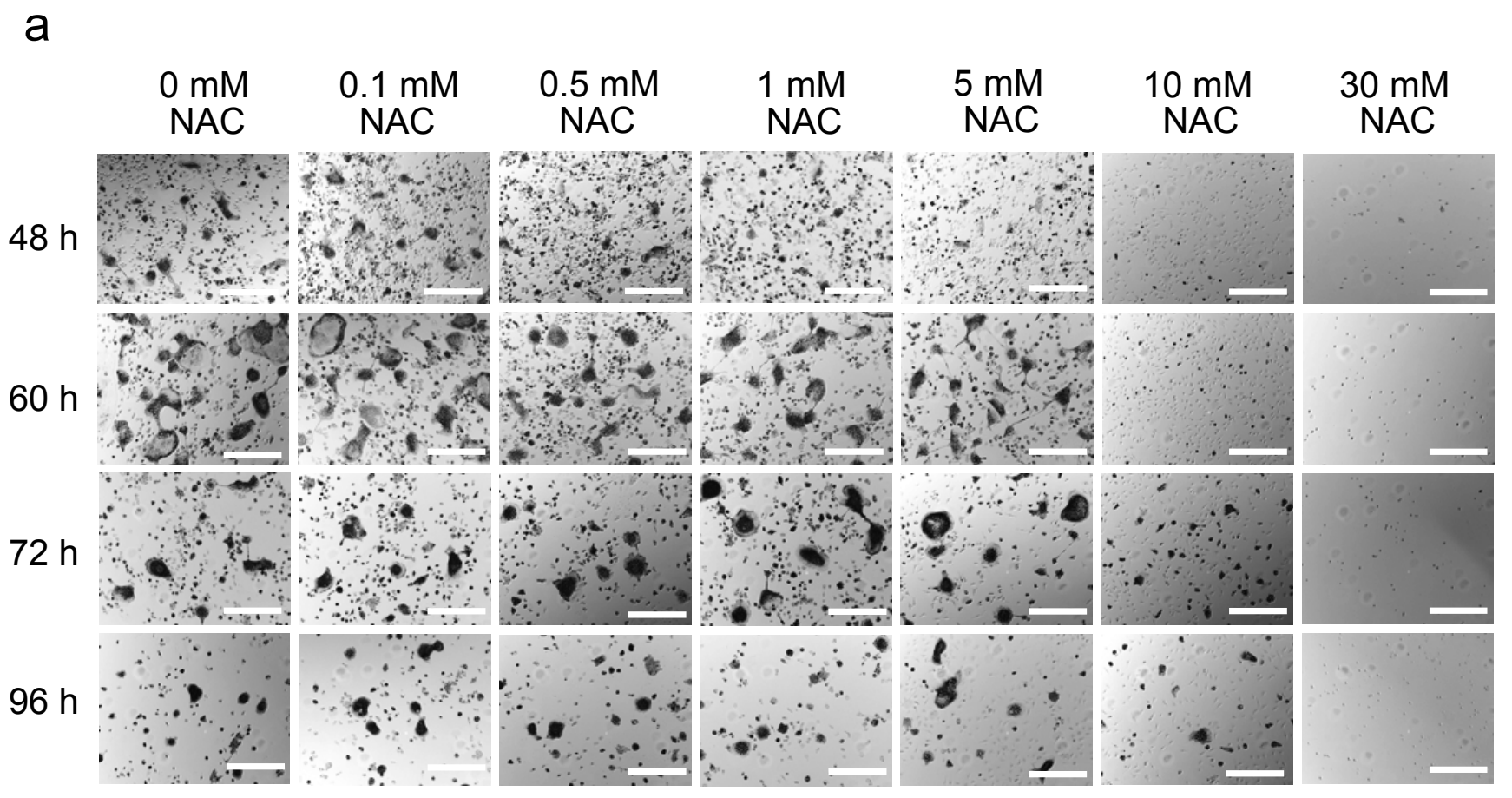

b

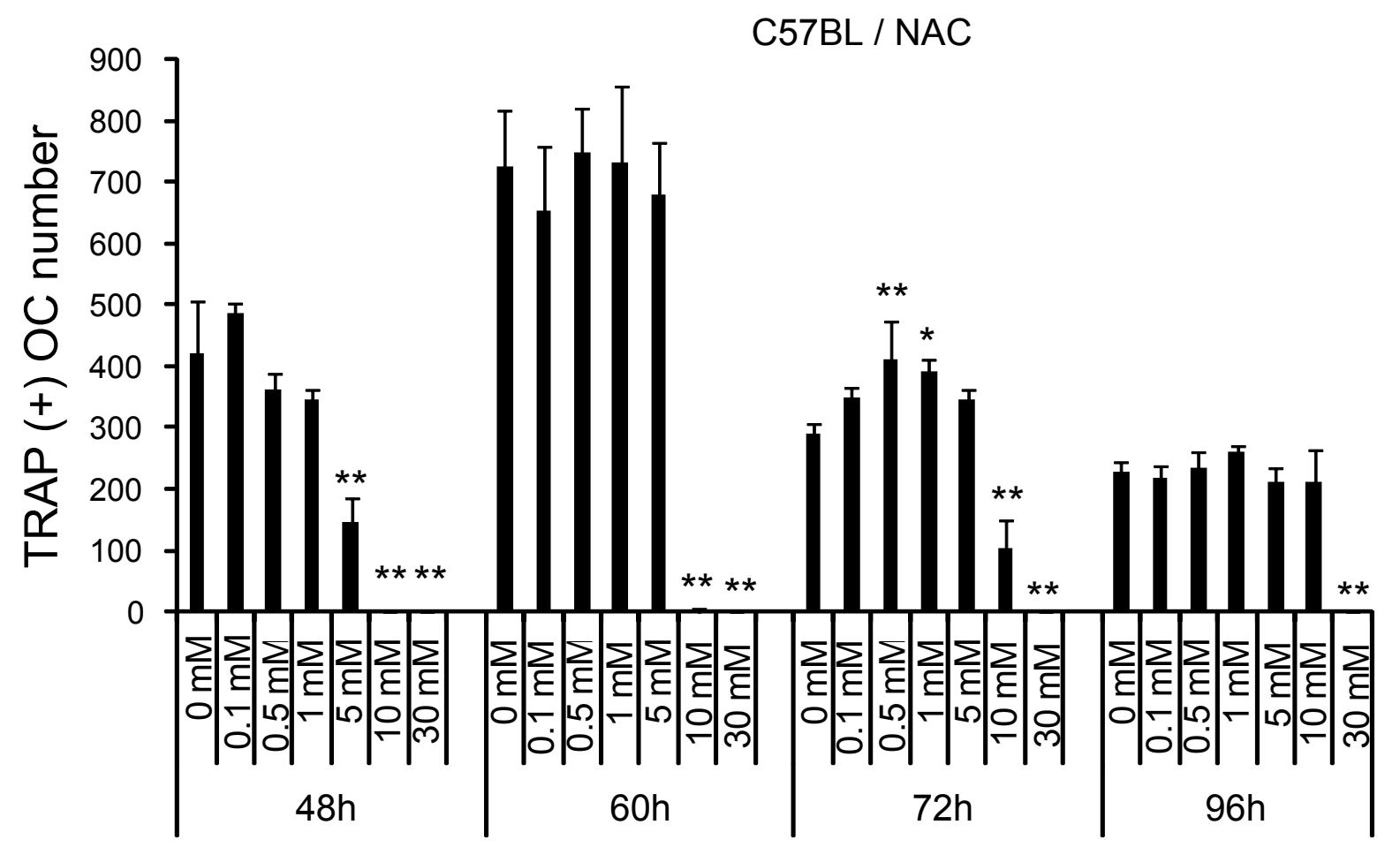

Fig. 8 
a

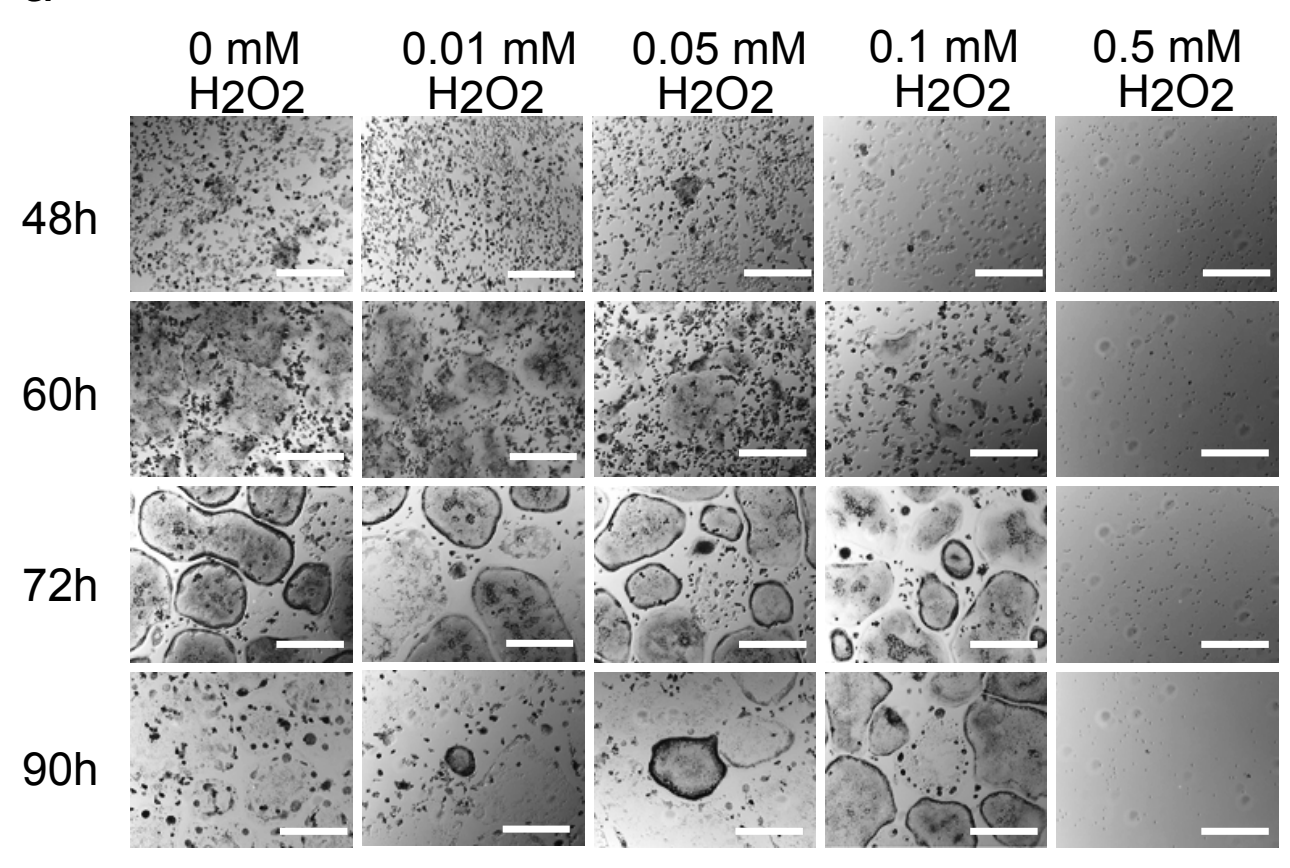

b

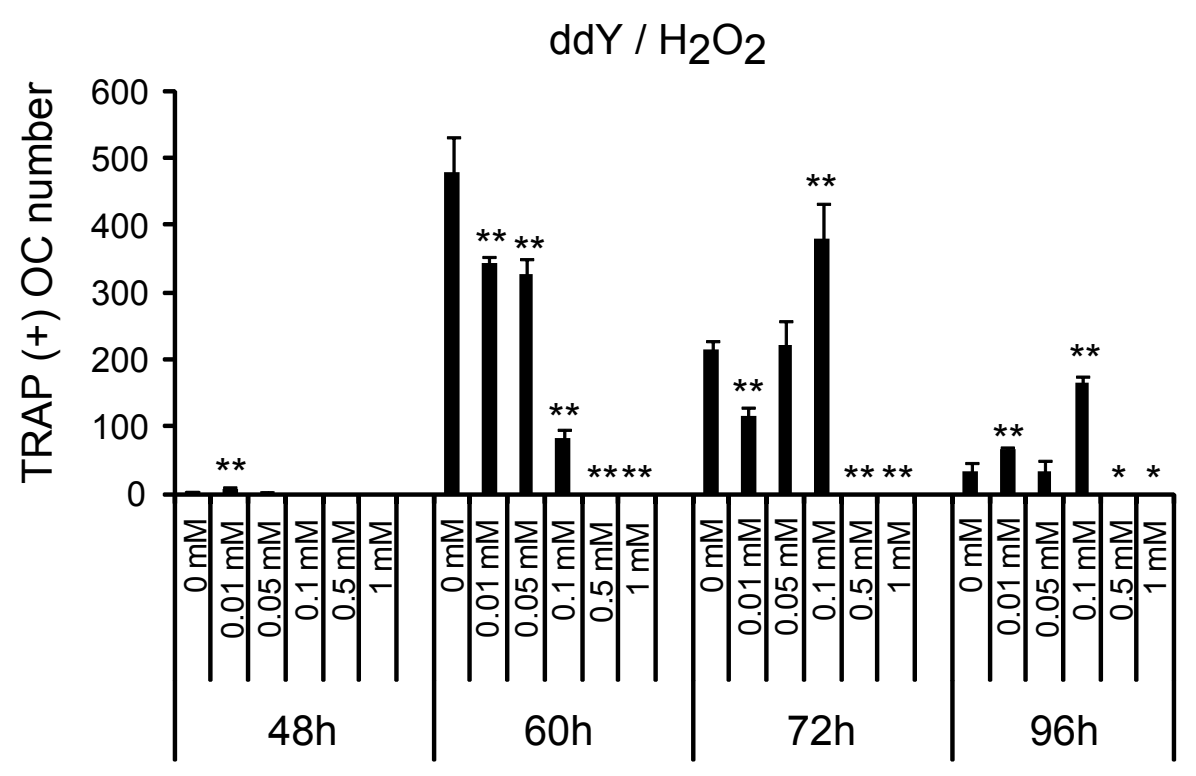

Fig. 9 
a

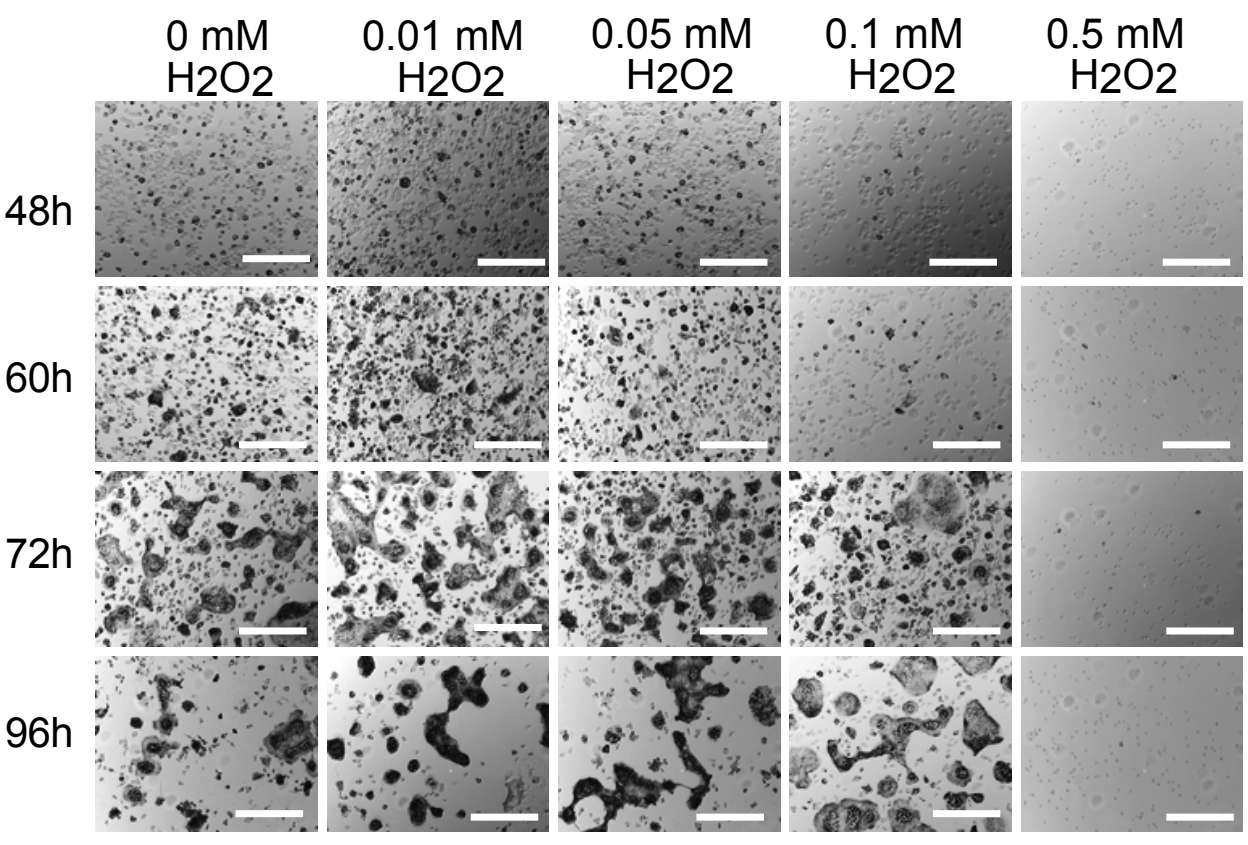

b

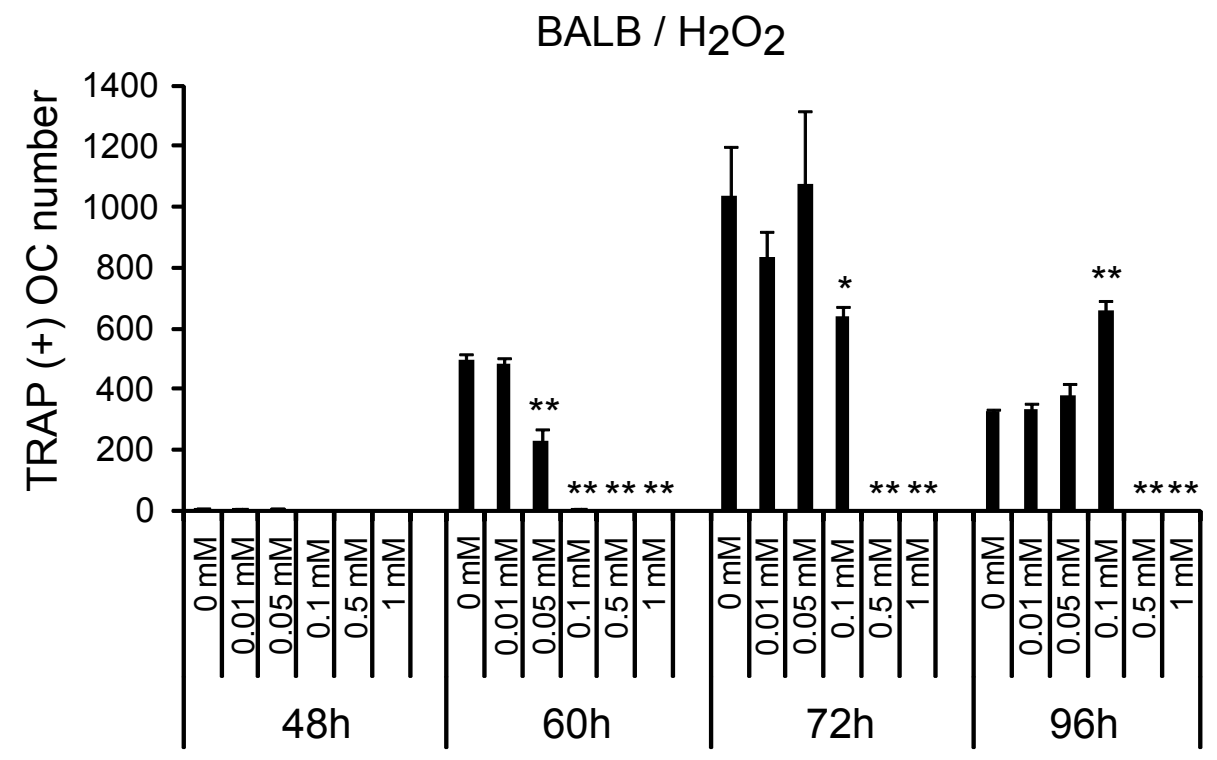

Fig. 10 
a

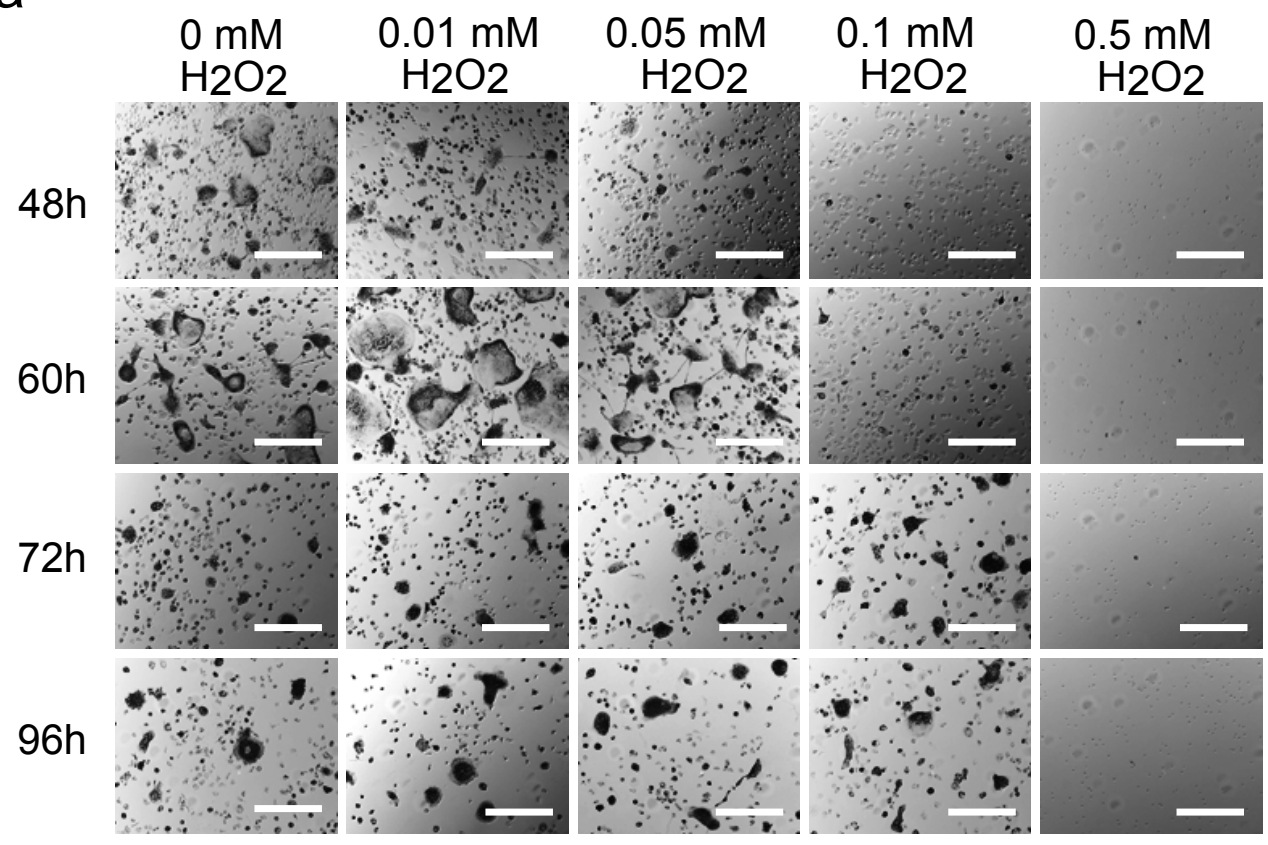

b

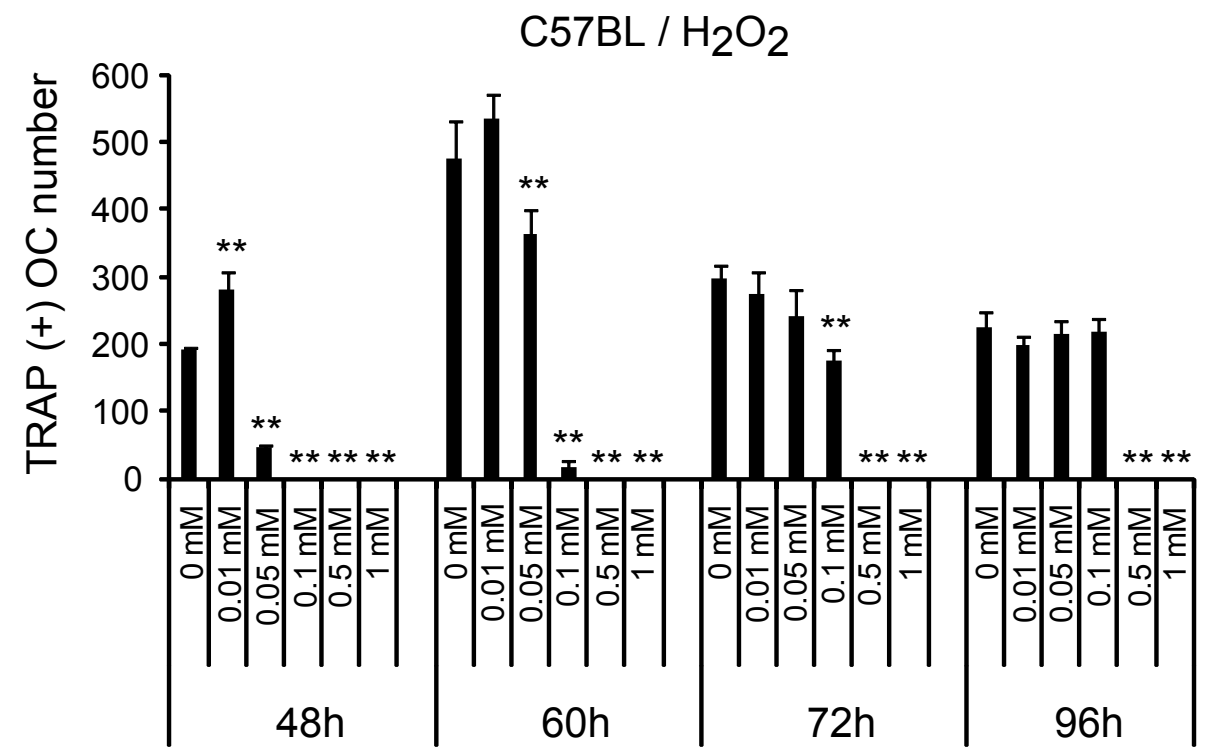

Fig. 11 
a

BALB/c

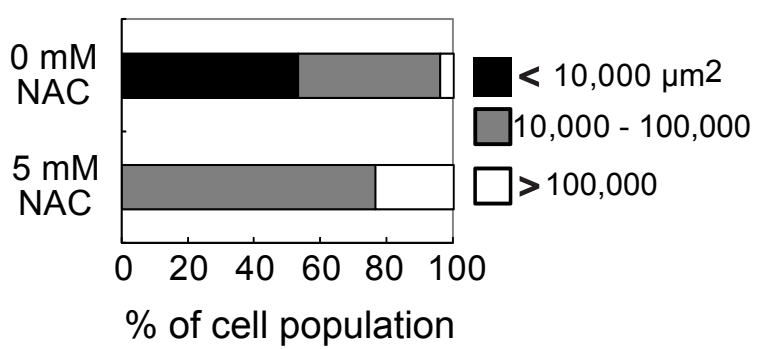

b

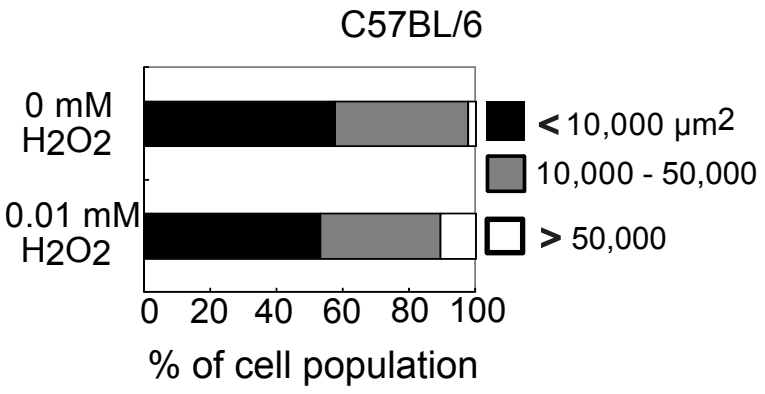

Fig. 12 